\title{
Epigenetic alterations in the suprachiasmatic nucleus and hippocampus contribute to age-related cognitive decline
}

\author{
Scott H. Deibel ${ }^{1}$, Erin L. Zelinski ${ }^{1}$, Robin J. Keeley ${ }^{1}$, Olga Kovalchuk ${ }^{2}$ and Robert J. \\ McDonald ${ }^{1}$ \\ ${ }^{1}$ Canadian Centre for Behavioural Neuroscience, Department of Neuroscience, University of Lethbridge, Lethbridge, AB, CAN \\ 2 Department of Biological Sciences, University of Lethbridge, Lethbridge, AB, Canada \\ Correspondence to: Scott H. Deibel, email: deibel@uleth.ca
}

Olga Kovalchuk, email: olga.kovalchuk@uleth.ca

Keywords: aging, brain, memory, circadian rhythms, Gerotarget

Received: March 10, $2015 \quad$ Accepted: April 15, $2015 \quad$ Published: May 08, 2015

This is an open-access article distributed under the terms of the Creative Commons Attribution License, which permits unrestricted use, distribution, and reproduction in any medium, provided the original author and source are credited.

\section{ABSTRACT}

Circadian rhythm dysfunction and cognitive decline, specifically memory loss, frequently accompany natural aging. Circadian rhythms and memory are intertwined, as circadian rhythms influence memory formation and recall in young and old rodents. Although, the precise relationship between circadian rhythms and memory is still largely unknown, it is hypothesized that circadian rhythm disruption, which occurs during aging, contributes to age-associated cognitive decline, specifically memory loss. While there are a variety of mechanisms that could mediate this effect, changes in the epigenome that occur during aging has been proposed as a potential candidate. Interestingly, epigenetic mechanisms, such as DNA methylation and sirtuin 1 (SIRT1) are necessary for both circadian rhythms and memory. During aging, similar alterations of epigenetic mechanisms occur in the suprachiasmatic nucleus (SCN) and hippocampus, which are necessary for circadian rhythm generation and memory, respectively. Recently, circadian rhythms have been linked to epigenetic function in the hippocampus, as some of these epigenetic mechanisms oscillate in the hippocampus and are disrupted by clock gene deletion. The current paper will review how circadian rhythms and memory change with age, and will suggest how epigenetic changes in these processes might contribute to age-related cognitive decline.

\section{INTRODUCTION}

"I have lost my rhythm. I can’t eat. I can’t sleep." Charles Bukowski, Metamorphosis.

As suggested by the quote, factors that affect physiology, such as aging, disease, or work schedule, can affect circadian rhythms, and disruption of these daily rhythms can be debilitating. Understanding the effects of the desynchronization of daily rhythms on health and well-being is of paramount importance because a myriad of disease states have been associated with circadian rhythm disruption, including heart disease and cancer $[1,2]$. Circadian rhythms and memory are among the physiological processes that decline during aging (for reviews see, [3, 4]). Memory and circadian rhythms are not separate processes, as circadian rhythm disruption can elicit memory impairments (for reviews see $[2,5,6]$ ). Circadian rhythm dysfunction could contribute to ageassociated cognitive decline, as the degree of circadian rhythm disruption has been positively correlated with mild cognitive impairment and memory impairment in aged humans and rodents, respectively [7, 8]. It is clear that alterations in circadian rhythms influence memory, but the nature and mechanism of this relationship is largely unknown.

The hippocampus is integral to the formation of memories. Its role in learning and memory formation has been widely studied and discussed throughout human and animal research. Clock genes and plasticity molecules oscillate in the hippocampus; however, it is unclear exactly how circadian rhythms affect memory acquisition, 
consolidation, retention, or recall [9-12]. Epigenetics are involved in circadian rhythm generation and memory formation. These epigenetic mechanisms also display age-related alterations in key brain regions that modulate circadian rhythms and memory $[4,13]$. The aims of the present article are three-fold. First, we will discuss how circadian rhythms and memory are intertwined and the specific involvement of epigenetics in these processes. Second, we will demonstrate that epigenetic modifications are involved in the age-related decline in these processes. Third, we will discuss recent data suggesting that agerelated cognitive decline could be due to altered epigenetic functioning in the hippocampus elicited by circadian rhythm disruption.

\section{Circadian rhythms}

Circadian rhythms are endogenously generated cyclical behaviours or physiological processes that take approximately 24 hours per cycle. The sleep-wake cycle, locomotor activity, temperature regulation, water/food intake, metabolism, and levels of circulating hormones are all physiological measurements of circadian rhythms $[14,15]$. Zeitgebers are environmental cues (such as light pulses, social activity, meals, or exercise) that synchronize an organism's endogenously generated rhythms with the environment [16]. Animals with circadian rhythms entrained to the environment have an advantage because they are able to anticipate daily events.

Though relatively small, the suprachiasmatic nucleus $(\mathrm{SCN})$ is the master pacemaker in the central nervous system. It consists of a pair of bi-lateral nuclei in the anterior hypothalamus, and SCN cells exhibit rhythmic oscillations in electrical activity and gene expression of specific genes coined 'clock genes', such as Clock (Clk), BMAL1, CRY and PER [17-20]. Recently, optogenetic stimulation or suppression of SCN neurons has suggested that SCN electrical activity determines the phase/period of clock gene oscillations in SCN neurons and in turn changes circadian locomotor activity [21]. Circadian rhythms are generated at the molecular level by rhythmic gene expression, which arises from an autoregulatory transcription/post-transcription/translation/ post-translational feedback loop [19]. Briefly, there are positive and negative limbs of this feedback loop, as CLOCK and BMAL1 activate the transcription of specific genes, whereas CRY and PER homologues repress the transcription of specific genes [19, 20]. CLOCK:BMAL1 heterodimers increase the transcription of CRY and PER homologues, while CRY:PER heterodimers inhibit their own transcription by decreasing CLOCK and BMAL1 expression $[19,20]$. The positive limb of this feedback loop is regulated by another feedback loop, in which BMAL1 transcription is activated and repressed by ROR $\alpha$ and REV-ERB $\alpha$, respectively $[19,20]$.

Although the $\mathrm{SCN}$ is a key circadian regulator, clock genes oscillate in other brain regions $[11,22]$ and peripheral organs [23]. The coordination of rhythms in most peripheral oscillators (the amygdala, neocortex, cerebellum, and hippocampus) depends on the SCN [2426]. Conversely, some oscillations are maintained in other peripheral tissues (the retina, cornea, pituitary, lung tissue, liver, olfactory bulb, arcuate nucleus, dorsomedial hypothalamus, and lateral habenula) for prolonged periods of time in the absence of the SCN $[22,27]$. However, cell synchrony within and between these tissues requires an intact and functioning SCN, providing further evidence that the SCN is a key circadian regulator $[22,27]$.

\section{Circadian rhythms influence learning and memory}

A long history of research has examined the role of the time of day and light-dark cycle alterations in memory formation. Certain rodents learn better at specific times of day or only retain information when training and testing occur at the same time of day, suggesting that the circadian system is involved in memory formation and recall [10, 28-32]. Rats can use circadian timers to solve timeplace-learning tasks wherein the response contingency is determined by the time of day $[33,34]$. Changing the light-dark cycle daily, or photoperiod shifting, disrupts memory for passive and active avoidance tasks [35-39]. However, it is unclear if this effect is transferable to other types of memory.

Episodic memories, which are memories for the time and place of personally experienced events, are particularly affected by aging $[40,41]$. In humans, disease pathologies, single unit recording, and functional magnetic resonance imaging have confirmed that the hippocampus is required for the encoding and recall of episodic memories [42-44]. With this in mind, we hypothesized that circadian rhythms might disrupt hippocampal-dependent memory in rodents [45]. Male rats exposed to a consecutive six-day photoperiod shifting paradigm, wherein the lights came on three hour earlier each day, had normal acquisition in the standard, spatial version of the Morris water task (MWT), but displayed impairments in long-term retention [45]. Longer periods of photoperiod shifting (e.g., several weeks) impair acquisition in this same spatial task [46]. While these data suggest that circadian rhythm disruption interferes with memory consolidation, it was unclear if circadian disruption could interfere with previously consolidated long-term memories. Animals that had acquired the spatial version of the MWT and were then exposed to brief or lengthy periods of photoperiod shifting had various degrees of hippocampal-dependent memory impairment, despite retention testing being conducted when the animal's circadian rhythms had re-entrained [5, $6]$. Additionally, photoperiod shifting alters performance in the hippocampal-dependent context-based discriminative fear conditioning tasks in mice and rats $[47,48]$. Thus, circadian rhythm disruption can affect consolidation and retrieval of long-term memories. 
Table 1: Key studies in chronological order that have demonstrated that circadian rhythm disruption elicit memory impairments in rodents.

\begin{tabular}{|c|c|c|c|}
\hline Study & Animal $\underset{\text { Species }}{\text { Sex/Strain/ }}$ & \begin{tabular}{|l|}
$\begin{array}{l}\text { Manipulation Used } \\
\text { to Induce Circadian } \\
\text { Rhythm Disruption }\end{array}$ \\
\end{tabular} & $\begin{array}{l}\text { Behavioural Task Used } \\
\text { to Detect Memory } \\
\text { Impairment }\end{array}$ \\
\hline 38 & Male albino rats & Photoperiod shifting & Passive avoidance task \\
\hline 7 & Male golden hamsters & Natural aging & $\begin{array}{l}\text { Appetitive contextual } \\
\text { conditioning }\end{array}$ \\
\hline 45 & Male Long-Evans rats & Acute $\begin{array}{c}\text { photoperiod } \\
\text { shifting }\end{array}$ & Spatial water task \\
\hline 46 & Male Long-Evans rats & $\begin{array}{c}\text { Acute and chronic } \\
\text { photoperiod shifting }\end{array}$ & Spatial water task \\
\hline 56 & $\begin{array}{c}\text { Male and female } \\
\text { Siberian hamsters } \\
\end{array}$ & Light pulse/phase delay & $\begin{array}{c}\text { Novel object recognition } \\
\text { task }\end{array}$ \\
\hline 49 & $\begin{array}{c}\text { C57BL6/J background } \\
\text { mice }\end{array}$ & Cry1Cry 2 mutation & Time-place learning task \\
\hline 50 & $\begin{array}{c}\text { Male C57BL/6 } \\
\text { background mice }\end{array}$ & Per 2 mutation & Trace fear-conditioning \\
\hline 48 & Male C57BL/6 mice & Photoperiod shifting & $\begin{array}{cc}\text { Contextual fear } \\
\text { conditioning }\end{array}$ \\
\hline 11 & $\begin{array}{c}\text { Male } \mathrm{C} 3 \mathrm{H} / \mathrm{J} \text { background } \\
\text { mice }\end{array}$ & Perl mutation & Spatial radial arm maze \\
\hline 51 & $\begin{array}{c}\text { Male } \\
\text { background mice }\end{array}$ & Bmal1 $\begin{array}{c}\text { mutation, } \\
\text { mutation }\end{array}$ & Open $\begin{array}{c}\text { field context } \\
\text { exploration }\end{array}$ \\
\hline 12 & Male C57BL/6 mice & SCN lesions & $\begin{array}{l}\text { Contextual fear } \\
\text { conditioning and spatial } \\
\text { water task }\end{array}$ \\
\hline 5 & $\begin{array}{c}\text { Male and Female Long- } \\
\text { Evans rats }\end{array}$ & $\begin{array}{c}\text { Chronic photoperiod } \\
\text { shifting }\end{array}$ & $\begin{array}{c}\text { Spatial water Task and } \\
\text { stimulus response visual } \\
\text { discrimination task }\end{array}$ \\
\hline 57 & Female Long-Evans rats & $\begin{array}{c}\text { Chronic photoperiod } \\
\text { shifting }\end{array}$ & $\begin{array}{c}\text { Appetitive context } \\
\text { discrimination }\end{array}$ \\
\hline 52 & $\begin{array}{c}\text { Male } \quad \text { C57BL/6 } \\
\text { background mice }\end{array}$ & Bmall mutation & $\begin{array}{l}\text { Contextual fear } \\
\text { conditioning and spatial } \\
\text { water task }\end{array}$ \\
\hline 32 & $\begin{array}{c}\text { Male } \quad \mathrm{C} 3 \mathrm{H} / \mathrm{HeN} \\
\text { background mice }\end{array}$ & Perl mutation & $\begin{array}{c}\text { Spatial working memory } \\
\text { task }\end{array}$ \\
\hline 6 & $\begin{array}{c}\text { Male and Female Long- } \\
\text { Evans rats }\end{array}$ & $\begin{array}{|cc|}\text { Acute } & \begin{array}{c}\text { photoperiod } \\
\text { shifting }\end{array} \\
\end{array}$ & Spatial water Task \\
\hline
\end{tabular}

In addition to environmental manipulations, physiological manipulations that affect circadian rhythmicity, such as clock gene mutations (Per1-/-: 11; Cry1-/- Cry2-/-: 49; Per2-/-: 50; Bmal1-/-: $51 ; 52 ; C l k: 51)$ or SCN lesions [12,53], can also elicit hippocampal-dependent memory impairments in rodents. Further, some cognitive disorders in humans (e.g., bipolar disorder) exhibit characteristic single nucleotide polymorphisms in several canonical clock genes [54, 55].

The precise mechanisms responsible for the influence of circadian rhythms on memory are unknown. There are a variety of possible mechanisms $[2,58]$. Clock genes and plasticity molecules, such as mitogen-activated protein kinase (MAPK), cyclic adenosine monophosphate (cAMP), $\mathrm{Ca}^{2+-}$ stimulated adenylyl cyclases, and Ras, exhibit circadian oscillations in the hippocampus [10-12, $50,59,60]$. All of these molecules have roles in long-term potentiation (LTP), the hallmark hippocampal processes thought to underlie memory formation. Thus, LTP decay and the magnitude of enhancement also oscillate [61, 62], and not surprisingly, mice with clock gene knockouts display impaired LTP (Per1-/-: 32; Per2-/-: 50; Bmal1-/-: 52). However, the circadian disruption experienced during shift work, transmeridian travel, and aging is not due to the deletion of clock genes, but instead it is believed to be due to an uncoupling of peripheral oscillators and the SCN $[2,63,64]$. Environmental light manipulations, such as photoperiod shifting, mimic this effect, as the phase relationship between clock proteins in the hippocampus and the SCN is changed in hamsters exposed to constant dim-illumination conditions [65]. Similarly, as suggested by Sidor and McClung [66], recently developed chronic optogenetic preparations might be useful in desynchronizing SCN oscillations from those in peripheral oscillators like the hippocampus.

Evidence to date suggests that the hippocampal 
oscillation of clock genes and plasticity mechanisms are driven by the SCN. For example, Per 2 oscillations in the dentate gyrus region of the hippocampus are dependent on the SCN [24]. However, Per2 will continue to oscillate in all hippocampal sub-regions in slice preparations (though coherence degrades over time), suggesting that the hippocampus is capable of semi-autonomous oscillations [50]. Additionally, the oscillation of synaptic plasticity molecules is dependent on the SCN [12], suggesting that clock gene oscillations are contributing to the rhythmic activity of these plasticity molecules in the hippocampus. For example, the rhythmic phosphorylation of cAMP binding protein (CREB) is dependent on Perl expression [32]. Similarly, MAPK and cAMP rhythms in the hippocampus are dependent on Bmall expression [52]. Since SCN ablation produces similar effects to global clock gene mutations, it is possible that hippocampal rhythms of plasticity molecules are dependent on hippocampal clock gene oscillations that are abolished by SCN lesions. Optogenetic manipulation of SCN activity, or hippocampus and SCN-specific clock gene knockout animal models would address this question.

There are a number of theories as to how circadian rhythms modulate memory. Memory formation in the hippocampus and zeitgeber responses in the SCN induce very similar molecular cascades [9]. In a sense, memory encoding might be time-stamped by integrating the current time of input with molecular oscillations [9]. Thus, EckelMahan and Storm [9] propose that memory encoding acts as a zeitgeber in the hippocampus by synchronizing molecular oscillations or by changing the rhythmic activity of neuronal ensembles. Recent empirical data support this view, as Ralph and Colleagues [67] demonstrated that the retention of a place memory (contingent on a specific time-of-day) eventually drifts to a new time in the absence of training and that this drift is dependent on the SCN. The authors hypothesized that there is a context-entrainable oscillator (CEO) that requires persistent input (training) to maintain time-of-day memory, and in the absence of memory training, the SCN acts as a weak zeitgeber that eventually entrains the CEO [67]. The hippocampus is a likely candidate for this CEO, as the task used in this study is hippocampal-dependent, and some of the molecular mechanisms of hippocampal-dependent memory are under circadian control.

In summary, circadian rhythms are involved in learning and memory, and hippocampal clock gene dysregulation and plasticity changes in specific biochemical plasticity pathways are likely responsible for the memory impairments associated with circadian rhythm disruption. However, there are other possible mechanisms by which circadian rhythm disruption could influence clock gene activity or other memory processes. Epigenetic changes have been proposed as a mechanism for circadian rhythms' modulation of memory because they are involved in the circadian clock and memory [58].

\section{Epigenetics}

Prior to the discovery of epigenetics, DNA was thought to determine phenotype exclusively. Phenotype can also be altered without a change in the underlying genome sequence, and this change is a result of epigenetic modifications [68]. Cell nuclei contain chromosomes that are composed of a complex of DNA and proteins called chromatin $[69,70]$. The repeating basic units of chromatin - nucleosomes - contain 147 base pairs of DNA wrapped tightly around octamers of histone proteins [6971]. Epigenetic modifications change chromatin state, producing states that either promote or suppress DNA transcription [70]. Heterochromatin consists of compacted chromatin and is associated with reduced gene expression $[70,72]$, whereas euchromatin promotes gene expression, as the chromatin is in an elongated state $[72,73]$. The two main epigenetic modifications include histone modification or direct action on DNA, such as DNA methylation [70, 72], and these changes can be transient [74] or long lasting and heritable [72, 74].

Histone modification occurs through enzymatic activity at the histone tail [69, 70, 72] and affects transcription by either elongating or condensing chromatin [70]. Although the specific function of a histone modification often depends on the conditions at that time, they can be broadly classified as either activating or repressive [70]. Acetylation and phosphorylation primarily activate transcription, while histone methylation, sumoylation, deacetylation, deamination, and proline isomerization are primarily repressive [70]. Furthermore, ubiquitination can be either activating or repressive, and even methylation can activate transcription in certain situations [70]. Some examples of molecules involved in histone modifications are those that add (histone acetyltransferase enzyme (HAT)) or remove (histone deacteylase enzyme (HDAC) acetyl groups from histones [70].

DNA methylation is the most commonly studied epigenetic mechanism, and in contrast to histone modifications, it exclusively represses transcription [72, 75]. DNA methylation typically involves the addition of methyl groups to cytosine bases that are bound to guanine via a phosphodiester bond (CpG dinucleotides) [72, 73, 75]. DNA methyltransferase enzymes facilitate DNA methylation by adding methyl groups to DNA [75]. The areas in the genome (primarily found in promoter and first exon regions of the DNA sequence) that have a high concentration of $\mathrm{CpG}$ dinucleotides are referred to as $\mathrm{CpG}$ islands [72, 73, 75-78]. CpG islands are typically umethylated so that transcription can occur $[73,75]$. Thus, the methylation of $\mathrm{CpG}$ islands down-regulates gene expression by blocking transcription [73]. In mammals, DNA methylation serves various functions, such as forming heterochromatin, imprinting, and X-chromosome inactivation [72]. However, variations in the amount of 
methylation over time can have deleterious effects. For example, in cancer cells, hypermethylation of tumor suppressing genes and hypomethylation of oncogenes can promote tumor growth and cancer progression [77, 79-85].

DNA methylated phenotypes can be transgenerationally heritable, whereas phenotypes due to histone modifications are generally considered nonheritable [86]. Unlike the relatively stable genome, the epigenome fluctuates and can change as a result of stochastic variation, aging, or exposure to environmental factors, such as nutrition and toxins [86, 87]. Epigenetic changes are more likely to occur during gestation rather than in adulthood, as chromatin modifiers are more active in early embryonic cells compared to adult cells [86]. Nonetheless, epigenetic changes also occur in adults [73, 86]. In adults, epigenetic changes are not global, and some tissues are more susceptible than others to specific environmental factors and their influence on epigenetic modifiers [86]. For example, chronic sun exposure and smoking preferentially elicit DNA methylation changes in skin cells and lung tumor suppressor genes, respectively $[88,89]$. Despite the negative connotations of epigenetic alterations, epigenetic changes can be beneficial, as they allow an organism to adapt to a fluctuating environment [74].

\section{Epigenetics and the circadian clock}

Epigenetic modifications show circadian rhythmicity and are regulated by core-clock genes $[32,90]$. In the SCN, DNA methyltransferase expression and phosphorylation of $\mathrm{H} 3$ histone tails are affected by the light-dark cycle and light pulses, respectively [91, 92]. Histone modifications can also be expressed rhythmically, as the acetylation of histones in Per1, Per2, and Cryl promoter regions has been shown to display circadian variation in mouse livers [93]. There is considerable variability in oscillatory expression of genes between tissues [94-96]. Consequently, Masri and Sassone-Corsi [97] suggested that peripheral tissue-specific gene oscillations might be a result of circadian fluctuations in chromatin states, which interact with the core clock machinery.

Since epigenetic mechanisms display rhythmic activity, not surprisingly, epigenetic modifications are directly involved in the core clock gene architecture. In addition to being a transcription factor, CLOCK is a HAT [98, 99]. CLOCK acetylates histones and non-histone proteins, such as its transcription partner, BMAL1, in a rhythmic fashion, which suggests that epigenetic modification is crucial to circadian rhythm generation [98, 99]. Interestingly, another epigenetic mechanism modulates the activity of BMAL1:CLOCK heterodimers, as a histone methyltransferase - mixed-lineage leukemia 1 (MLL1) - enhances the transcriptional activation properties of BMAL1:CLOCK heterodimers and is required for the oscillation of all the core clock genes [100].
Given that CLOCK activates transcription by remodeling chromatin, researchers have hypothesized that there might be a circadian clock component that epigenetically represses transcription. The HDAC, sirtuin 1 (SIRT1) is a likely candidate $[101,102]$. SIRT1, which is highly expressed in the hippocampus, cortex, cerebellum, and hypothalamus [103], is a metabolic sensor that affects cellular energy via its cofactor and activity regulator, nicotinamide adenine dinucleotide (NAD $;[13,102])$. SIRT1 is involved in a variety of functions, such as neurogenesis, synaptic plasticity, DNA repair, cell cycle arrest, cell survival, gluconeogenesis, lipid metabolism, insulin sensitivity, and protection against brain pathology associated with AD [13, 102, 104, 105].

SIRT1 was recently discovered to have a role in the molecular generation of circadian rhythms. The central function of SIRT1 is likely epigenetic [106], and SIRT1 contributes to circadian rhythmicity by rhythmically deacteylating BMAL1 and PER2 [107, 108]. SIRT1 primarily down-regulates BMAL1:CLOCK initiated transcription by affecting CLOCK and BMAL1 acetylation [107, 108]. SIRT1 oscillates in the SCN and hippocampus $[32,109]$. There is a regulatory loop in the SCN consisting of the oscillatory proteins SIRT1, PPARg coactivator 1a (PGC-1a), and the NAD+ synthetic enzyme nicotinamide phosphoribosyltransferase (NAMPT; [109]). Together, this regulatory loop influences aspects of circadian rhythmicity, such as the free-running period [109]. SIRT1 directly regulates circadian rhythmicity, as mice lacking SIRT1 in brain [109] or liver tissue [108] had longer free-running periods/reduced activity and disrupted clock gene expression in the liver, respectively. Conversely, mice over-expressing SIRT1 in the brain had shorter free-running periods and increased amounts of activity [109].

\section{Circadian rhythms and epigenetics interact synergistically}

Chronotype refers to an individual's preferred time of day (morning or evening) and sleep schedule [110, 111]. Genetics and zeitgeber exposure are thought to determine chronotype [110, 111]. Barclay and colleagues [111] demonstrated that monozygotic twins exposed to different life experiences had different chronotypes, indicating that environment can influence chronotype. A study in mice indicated that chronotype can vary within inbred mice that have very similar DNA [112]. Interestingly, these changes arose in mice that were housed in identical environmental conditions. However, the authors suggest that endogenous epigenetic changes could have influenced chronotype, and this fits with findings suggesting that the epigenome can vary stochastically, independent of environmental manipulations [86, 112].

Although these studies in animal models suggest that epigenetic mechanisms influence chronotype, this phenomenon has not received much attention in the literature on humans. Only a handful of studies have 
suggested that DNA methylation influences chronotype in humans. For example, the gene for the cytokine tumor necrosis factor alpha (TNF- $\alpha$ ), which among other things is involved in cell survival, had higher levels of methylation from peripheral blood samples collected from shift workers with a late chronotype rather than an early one [113]. Similarly, there was a nonsignificant trend for late chronotypes to have increased CLOCK gene methylation expression in white blood cells [114].

Similar to the notion that epigenetics can affect chronotype or circadian phenotype, epigenetic modifications are involved in entrainment to a new photoperiod. In this study, there were global transcriptome changes in DNA methylation in the SCN of mice that had entrained to a novel photoperiod [91]. The authors hypothesized that free-running period adjustment is mediated by DNA methylation. This conclusion seems likely, as a DNA methyltransferase inhibitor, which decreases DNA methylation, prevented entrainment to the novel photoperiod [91]. Shorter photoperiods reduce DNA methylation of a hypothalamic gene involved in sexual reproduction, suggesting that reversible epigenetic modifications are involved in adapting physiology to seasonal environmental variations [115]. Collectively, these data suggest that epigenetic changes induced by environmental manipulations or internal stochastic variation can influence the free-running period of circadian rhythms.

\section{Circadian rhythm disruption influences the epigenome}

Since epigenetic modifications are involved in circadian rhythms, it is likely that epigenetic variation elicited by circadian rhythm disruption can negatively impact health. It is believed that shift-workers are prone to various disease states because they are in a state of constant circadian disruption [116-118]. Changes in the epigenome have been suggested as a possible mechanism for the deleterious effects of circadian disruption on health $[58,73,119]$.

Various studies have investigated DNA methylation in shift workers. One study demonstrated that shift-workers have reduced CLOCK and increased CRY2 methylation in peripheral blood samples relative to day workers [119]. The association between altered metabolic processes and shiftwork is exemplified via the link between shiftwork and cancer [120]. Breast cancer rates are elevated amongst shift-workers, and breast cancer patients express CLOCK hypomethylation [121] and CRY2 hypermethylation [122] in blood and tumorous breast tissue. In a phenomenon called genomic imprinting, epigenetics can silence an allele inherited from one of the parents so that gene expression is determined from only one inherited allele [123]. Several imprinted genes associated with cancer were differentially methylated in blood samples from shift-workers compared to day workers [124]. The amount of time working on a shiftwork schedule also affects the epigenome, as Bolatti et al. [113] showed increased global hypomethylation on specific repetitive elements in the blood of long-term shift-workers. Interestingly, in these long-term shift-workers, TNF- $\alpha$ and a cytokine involved in tumor regulation, interferon-gamma (IFN- $\gamma$ ), were also hypomethylated [113].

Free-running periods are affected by epigenetic modifications. A micro RNA (miRNA) involved in regulating free-running circadian rhythm period length (miR-219) was hypermethylated in the blood of female shift workers [125]. These data support the notion that DNA methylation and changes in miRNA activity, which is another epigenetic mechanism, are involved in regulating the period of circadian rhythms, as these workers were likely in a state of chronic circadian disruption [116-118].

Very few animal studies have investigated the effects of circadian rhythm disruption on the epigenome. Human shift-work data have been corroborated in mice via the demonstration that light periods during the normal dark phase (aka, light at night; LAN) elicit global DNA hypomethylation in breast cancer tumors [126]. Melatonin is a rhythmically expressed hormone secreted by the pineal gland that, in addition to being a hormonal regulator of circadian rhythms, also suppresses the growth of breast cancer cells [73]. Melatonin release is attenuated and non-rhythmic in circadian disrupted individuals, which might contribute to the higher prevalence of cancer in shift workers $[73,126]$. Interestingly, this effect is thought to be due to melatonin's hypothesized role in silencing genes via epigenetic mechanisms [73]. Thus, Schwimmer and colleagues [126] demonstrated that exogenous melatonin supplementation significantly reduced tumor growth and hypomethlyation that was induced by LAN, suggesting that melatonin suppression may be the mechanism underlying the consequences of LAN on DNA methylation. Similarly, in a rat model, we demonstrated that chronic circadian rhythm disruption induced by a lengthy period of photoperiod shifting, up-regulated some miRNAs that are indices of cancerous tissue and downregulated some miRNAs involved in tumor suppression (Kovalchuk \& McDonald, unpublished).

As a whole, data indicate that circadian rhythm disruption changes the epigenome, but the permanence of epigenetic changes induced by circadian disruption is unknown and requires further investigation. Similar epigenetic changes in shift workers and cancer patients support the hypothesis that shift work acts as a carcinogen. One caveat of the human shift-work studies mentioned above is that most of them assessed DNA methylation in peripheral blood [121]. Epigenetic modifications can be tissue specific [86], and, as with any environmental manipulation or toxin, it is likely that some tissues are more susceptible to the harmful effects of circadian disruption. Increasing the number of studies implementing animal models of shift work will ensure a more thorough understanding of the effects of circadian disruption on the 
epigenome.

\section{Epigenetics regulation of memory formation and recall}

Epigenetic changes, such as histone acetylation, phosphorylation, methylation, and especially DNA methylation, are involved in memory $[127,128]$. Learning of hippocampal-dependent tasks induces epigenetic changes in the hippocampus and other brain areas to support memory formation. For example, the acetylation of histones in the hippocampus is increased shortly after contextual fear conditioning and MWT training [129, 130]. The nature of the behavioural task employed dictates which brain areas will undergo epigenetic changes. For example, acetylation occurs in the hippocampus and striatum during hippocampal- and striatal-based tasks, respectively, which suggests that this acetylation is associated with learning [130]. Furthermore, transgenic mice with disrupted CREB binding protein (CBP), which is a HAT, are impaired in various hippocampaldependent tasks [131, 132]. Furthermore, the inhibition of an HDAC in a mouse model rescued fear conditioning retention and late-phase LTP [131]. In these studies, the impairments in spatial learning tasks - the gold standard measure of hippocampal functioning - were exclusive to CBP transgenic animals, in which the HAT region is specifically targeted, rather than a partial CBP deletion [128, 131, 132]. Inhibiting HDACs can enhance aspects of contextual fear conditioning and spatial memory, which further supports an integral role of histone acetylation for memory [128, 131, 133, 134]. Histone phosphorylation is also involved in hippocampal-dependent memory, as H3 phosphorylation, which is dependent on the ERK/MAPK pathway (under circadian control), is increased in the CA1 region of the hippocampus following fear conditioning [135].

Epigenetics is likely a conserved mechanism. Consequently, some of the epigenetic modifications involved in circadian rhythms (e.g., DNA methylation) are shared with learning and memory. DNA methyltransferase expression, which facilitates DNA methylation, is increased in the hippocampus following contextual fear conditioning [136]. Blocking these training-induced changes in DNA methylation shortly after [136] or 30 days [137] after training resulted in memory impairments. Training-induced changes in DNA methylation are gene dependent, as increased demethylation and methylation of memory promoting and suppressing genes, respectively, occur in the hippocampus shortly after contextual fear conditioning $[128,136]$. In one study, DNA methylation was present in the anterior cingulate cortex up to 30 days after contextual fear conditioning, suggesting that learning induced epigenetic changes can be long lasting [137].

SIRT1, an HDAC involved in the autoregulatory feedback loops of circadian rhythm generation, is also necessary for long-term memory [104]. SIRT1 regulates miRNA-134, which affects the brain-derived neurotropic factor (BDNF) and CREB [104, 128]. Both BDNF and CREB are required for synaptic plasticity, which is crucial for learning and memory [4, 104, 138-141]. In addition to having disrupted circadian rhythms, SIRT1 knockout mice have impaired LTP, and these mice are impaired in contextual and cued fear conditioning, short-term memory, and spatial learning (MWT; [104, 105, 109]).

\section{Aging}

\section{Circadian rhythms degrade with age}

Many aspects of circadian rhythmicity are affected by aging [3]. Changes to the length [142-147] and amplitude [144, 146-149] of the activity period have been observed in rodents. Rhythm fragmentation in rodents increases with age and results in the timing of behaviour or other processes under circadian control occurring at atypical times of day [147, 150]. Finally, the circadian clock is not as plastic with advanced age, making it harder for rodents to entrain to new light-dark cycles [91, 109, 147].

In addition to activity rhythms, aging affects other circadian processes. For example, daily fluctuations in hormone levels are disrupted in aged humans [151, 152] and other animals [28, 153]. In animal models, corticosterone and melatonin are strongly affected by aging, as basal levels can change, or the hormones no longer oscillate [28, 153-155]. In humans, the peak amplitudes of temperature and melatonin expression decrease with age; however, men may be more affected [151, 156-158].

Sleep is also affected by aging, with the amount of rapid-eye-movement sleep increasing and the amount of slow-wave sleep (SWS, a stage of non-rapid-eyemovement sleep) decreasing with age. Some theorize that episodic memory consolidation occurs during SWS, which decreases with age [159]. Other components of sleep that are hypothesized to contribute to memory consolidation, such as K-complexes and spindles, are also reduced in aged humans [160]. Similarly, a person's chronotype changes with age, as early chronotypes predominate in the elderly and not in younger or middle-aged people [110].

It is generally assumed that the impairments in circadian rhythm output are due to aging-induced changes in SCN functioning. Although SCN cell loss is not common in aged rodents, neurotransmitter modulation of SCN function is not as effective, and the subpopulations of cells expressing these molecules are often diminished in aged individuals [161]. For example, the number of GABAergic synapses [162] and VIP/VIP receptor expression are attenuated in the SCN of aged rodents [161, 163, 164]. As a result, aging SCN cells lose synchronicity, which could affect circadian rhythm amplitude and period [161]. Circadian rhythms are less plastic in aged individuals, and SCN activity in response 
to light is diminished in aged rodents and primates [165167]. Several studies demonstrate that a malfunctioning SCN contributes to circadian rhythm deterioration in aged individuals; remarkably, transplanting fetal SCN tissue into the third ventricle of an aged animal partially rescues circadian rhythmicity in rats and hamsters [165, 168-170].

The oscillatory expression of some clock genes in the SCN of rodents is affected by aging; Perl [171], Per2 [171, 172], Cryl [171], Cry2 [171], Clk [173, 174], and Bmall [171, 173] mRNA oscillations are disrupted or abolished in aged rodents. Oscillating tissue outside of the SCN is also affected by aging, as the amplitude and/or rhythmicity of Clk and Bmall are altered in the hippocampus and other brain regions of aged mice [174]. Changes in the phases of Per1, Per2, and Bmall oscillations are observed in the brain tissue of AD patients [175]. In addition to molecular oscillations, oscillatory electrical activity is also affected by aging. The peak of electrical activity in the SCN usually occurs during midday; however, in aged mice, similar to locomotion, there is more electrophysiological activity during the expected nadir [176]. Similarly, the amplitude and period of SCN neuron electrical oscillations in in vitro preparations is affected by aging [177].

While it is clear that circadian rhythms deteriorate with age, it appears that this relationship is synergistic because circadian rhythmicity affects longevity. Tau mutant hamsters, who display decreased life spans, possess naturally fragmented circadian rhythms, and transplanted fetal SCN tissue into the third ventricle of aged mutants increased their lifespan [168]. Similarly, Tranah and colleagues [178] observed that elderly women with fragmented circadian rhythms had shorter life spans. It is possible that clock gene expression altered by aging might be the mechanism responsible for decreased longevity in circadian-disrupted individuals, as Bmall [179] and Clk [180] knockout mice have reduced life spans. Bmall knockout mice also have age-related pathologies, such as sarcopenia, osteoporosis, cataracts, less subcutaneous fat, decreased hair growth, organ shrinkage, and changes in peripheral blood composition [179]. Alternatively, circadian rhythm disruption could affect the expression of other proteins involved in aging and longevity such as apolipoprotein E [181] and D [182] proteins, which are involved in lipid transport.

Although the SCN is likely responsible for the circadian rhythm age-related decline, the mechanisms eliciting the SCN malfunction are still largely unknown. Recently, epigenetic modifications have been proposed as an alternative mechanism for the degradation of circadian rhythms [13, 91, 109].

\section{Memory declines with aging}

As discussed in a thoughtful review by Penner and colleagues [4], age-related memory impairment is common and can be debilitating. The degree of memory impairment varies from the more prevalent cases of mild, age-associated memory impairment to the rarer cases of severe, profound dementia [4, 183]. Normal aging [40] and dementias, such as AD [184, 185], are characterized by progressive loss of the ability to form and recall episodic memories. Hippocampal-dependent spatial navigation tasks are commonly used as a model for episodic memory in humans and animals [186-188]. Aged rodents are impaired in a myriad of hippocampaldependent measures, including spatial navigation tasks [4, 130, 188-197].

Hippocampal cell death in aged humans, monkeys, and rodents is minimal [198-201]. However, the aged hippocampus is more sensitive to the negative impacts of damaging agents. For example, aged rats given minihippocampal strokes had larger lesions, more damaged cells, and exacerbated spatial impairments relative to younger rats [202]. Despite there being little concomitant hippocampal cell death associated with aging, various aspects of hippocampal functioning are compromised in aged individuals. In rats, the induction and maintenance of LTP are affected by aging [4, 188, 189, 203-207].

The minimal hippocampal cell death associated with aging implies that it is likely that plasticity mechanisms are affected by aging [4]. Various molecular mechanisms are required for memory [208], but the immediate early gene BDNF is of particular interest [209]. BDNF is widely expressed in the hippocampus and is involved in synaptic plasticity and thus memory [4, 139]. BDNF is up-regulated after training in hippocampal-dependent memory tasks [4, 139-141], and LTP/hippocampal-dependent memory is impaired in BDNF knockout mice [4, 139, 210, 211]. Hippocampal expression of BDNF and its receptor can be decreased in middle-aged and aged rats, although this effect is strain specific [4, 212-215]. In addition to BDNF, other immediate early genes are also down-regulated in the hippocampus of aged rats with concomitant memory impairments [4, 216, 217].

Another way of assessing hippocampal function is to assess electrophysiological correlates in freely moving animals. Hippocampal place cells fire when an animal is in a particular location of the environment [218, 219]. Recently, place cells have been hypothesized to be involved in more than the representation of spatial locations [220, 221]. For example, place cells are involved in the memory for sequences of events that comprise behaviour, as certain place cells will only fire depending on where the animal has just been or where it is planning to go [220, 222-225]. Several aspects of place cell functioning in rats are affected by aging. For example, in aged rats, place cells have decreased spatial specificity, and they are less likely to change their location when cues are altered in a familiar environment [191, 226, 227]. Furthermore, during the first few minutes of exposure to a novel environment, place fields expand [228], and this experience-dependent plasticity is abolished in aged 
rats [197]. Place field stability is also affected by aging; Barnes et al. [191] showed that although place fields of aged rats were stable while in an environment, these cells would remap when the animals were returned to a familiar environment. Similarly, the tuning of place cells to spatial cues and place field stability are impaired in aged mice [229].

The hippocampus replays activation sequences of previously experienced behaviours while awake [230] and at rest [231-233]. While the exact function of replay is still under debate [234], some of the literature suggests that it is involved in the consolidation or retrieval of episodic memories [233]. Age-induced memory impairment might occur because memory consolidation is impaired by disrupted replay, or memory reactivation [193]. Gerrard and colleagues [194] observed that sequential reactivation was impaired in aged animals, such that the temporal bias for a cell to fire just prior to the firing of another cell was abolished. The altered neurobiology was corroborated behaviourally as animals with poor sequential reactivation displayed greater impairments in a hippocampal-dependent task than those with superior sequential reactivation. These results suggest that aging affects hippocampal replay, and the memory impairment in aged animals could be partially due to the failure of cells to be reactivated in the correct temporal order during sleep.

\section{Circadian rhythm disruption might contribute to age- related cognitive decline}

The link between circadian rhythms and memory is further bolstered by data from aged individuals. For example, age alone is not the best predictor of cognitive impairment, as Antoniadis et al. [7] demonstrated that older hamsters with disrupted circadian rhythms were more impaired in a hippocampal-dependent task when compared to hamsters of the same age with entrained circadian rhythms. This effect has been observed in humans, as older women with weak circadian rhythms are reportedly more likely to develop dementia or mild cognitive impairment than age- and health-matched women with robust circadian rhythms [8].

Age-associated dampening of hormonal rhythms, such as melatonin and corticosterone, contribute to age-associated memory impairments. Hamsters with decreased baseline corticosterone and corticosterone rhythm amplitude showed greater impairments in a hippocampal-dependent task than aged-matched controls with robust corticosterone rhythms [28]. Cermakian and colleagues [175] have reported reduced synchronization of clock gene activity across brain regions in Alzheimer's patients, including the pineal gland - an important site for the secretion of melatonin. Attenuated hormonal rhythms that arise during aging could affect clock gene oscillations in the SCN and peripheral oscillators, as exogenous melatonin has been shown to improve SCN clock gene rhythmicity in aged animals [171].

Furthermore, place cell stability, formation, and reactivation are compromised in aged rodents [191, 193, 194, 197, 226, 227, 229], and in rats, the firing of hippocampal CA1 pyramidal (place) cells display circadian rhythmicity that is thought to be entrained by entry into the environment or availability of food [235]. The authors hypothesized that this rhythmic activity might be involved in encoding temporal information. It is possible that circadian rhythm disruption affects place cell activity and thus could be contributing to age-associated memory impairment.

Circadian disruption impairs memory and is correlated with the degree of memory impairment in aged animals. These results suggest that circadian disruption contributes to hippocampal pathology in aged individuals.

\section{The epigenome changes during aging}

Epigenetics represent an interesting mechanism for age-related changes in phenotype because the epigenome is heritable but also affected by the environment [236]. The epigenome changes with age, as in humans, global DNA hypomethylation is generally associated with aging [236-239]. Not surprisingly, DNA methyltransferases (DNMT1 and DNMT3a) are reduced during aging [239]. Histone acetylation and methylation patterns also change with age [240-242]. Epigenetic changes are also associated with $\mathrm{AD}$, as the amount of DNA methylation and hydroxymethylation (oxidized DNA methylation) in the brains of AD patients is positively correlated with markers of AD, such as beta amyloid, tau, and ubiquitin load [243].

Work from Kovalchuk and colleagues have contributed to the notion that epigenetic changes occur in senescent (involved in the terminal cell cycle arrest of cells) cells. For example, DNA methylation and histone methylation (K20-H4) are significantly reduced in breast cancer cells, and this reduction is likely due to the attenuated expression of molecules involved in histone and DNA methylation, such as the histone methyltranferase (SUV39H1) and methyl binding proteins [79]. Lung cancer senescent cells also demonstrate global DNA hypomethylation [244], as well as reductions in global histone trimethylation ( $\mathrm{H} 3 \mathrm{~K} 9$ trimethylation) and a histone methyltransferase (SUV39H1) [245].

Epigenetic changes are often tissue specific, as environmental factors affect some tissues more than others [86]. For example, age-related decline in the immune response might contribute to the development of cancer and other age-related pathologies [246]. Interestingly, in aged rats, hypomethylation of histones and DNA occurs in the primary (thymus) organ involved in immune response, and histone hypomethylation also occurs in the secondary (spleen) organ involved in immune response [246].

As mentioned in the beginning of this review, SIRT1 is a HDAC that is involved in circadian rhythm 
generation and memory. While a variety of epigenetic changes occur during aging, SIRT1 activity is a key player in the aging-associated phenotype. For example, SIRT1 is neuroprotective against neurodegenerative age-associated pathologies such as AD; thus, it has been implicated in promoting longevity and healthy aging [102, 247, 248]. Specifically, SIRT1 activation decreased neurodegeneration, the amount of beta amyloid formed, and improved memory in animal models of AD [249, 250]. Furthermore, SIRT1 expression is attenuated in senescent cells, the thymus, the testis, and in the skin of a transgenic mouse model that accelerates aging [239, 242, 251]. Conversely, mice that overexpress SIRT1 in the brain live longer and display delayed aging compared to wild-type animals [252].

\section{The epigenome in the SCN and hippocampus is affected by aging}

In aged rodents, epigenetic changes occur in areas of the brain that modulate memory and circadian rhythms. As highlighted in the beginning of this review, SIRT1 and DNA methylation are both necessary for circadian rhythms and memory. Aging elicits similar changes to these epigenetic mechanisms in the hippocampus and SCN. Although this is a burgeoning research field, convincing evidence from several studies indicates that the epigenome in these brain areas is affected by aging.

\section{Memory}

Recent evidence suggests that the epigenetic changes that underlie learning and memory are affected by aging. For example, shortly after spatial learning and contextual fear conditioning, histone 4 acetylation in the hippocampus of aged mice (CA1 and DG) is downregulated and HDAC inhibitors rescue acetylation and the concomitant learning impairments [130, 195]. Age-related dysregulation of learning-induced histone acetylation is specific to the brain area modulating that specific learning task. For example, the age-related acetylation dysregulation is only seen in the hippocampus or striatum when spatial (hippocampal-dependent) and cue-based (striatal-dependent) versions of the MWT are used, respectively [130]. When mice have the option of using a place or cue strategy in MWT, a histone deacteylase inhibitor delivered to the CA1 region of the hippocampus results in a bias for a hippocampal-dependent place strategy, but this effect is lost in aged mice [253].

Similarly, Penner and colleagues [196] observed altered hippocampal DNA methylation of an immediate early gene required for memory consolidation, the activity-regulated cytoplasmic gene (ARC), which likely contributes to reduced $A R C$ mRNA expression and concomitant impairments in the MWT. SIRT1 protein levels in the hippocampus are also decreased in aged rats, while expression in the cerebral cortex is unaffected [254]. This attenuated hippocampal expression is due to posttranslational modifications, as SIRT1 mRNA expression is maintained in aged rats [254]. Decreased SIRT1 in the hippocampus might contribute to age-related memory impairments, as transgenic mice with SIRT1 deletions are impaired in hippocampal-dependent tasks $[104,105]$. However, until mice with a SIRT1 deletion specific to the hippocampus are trained in a hippocampal-dependent task, this claim cannot be verified.

\section{Circadian rhythms}

Recent studies have indicated that epigenetics are involved in the circadian rhythm dysfunction that occurs with aging. Readers are encouraged to see the review by Orozco-Solois and Sassone-Corsi [13], which discusses how the involvement of epigenetics in circadian rhythms might affect aging. In the SCN of aged mice, the reduction of a primary DNA methyltransferase was associated with disrupted circadian rhythms and the inability to entrain to a slightly shorter light-dark cycle [91]. As changes in DNA methylation regulate circadian rhythm entrainment, the authors hypothesized that age-related changes in SCN DNA methylation might explain why chronotype changes with age $[91,110,113,114]$.

In addition to age-associated cognitive decline, Chang and Guarente [109] unequivocally demonstrated that SIRT1 degradation contributes to circadian dysfunction in aged mice. As the deletion of SIRT1 expression in the brain creates a free-running period and a disrupted activity pattern that is similar to that in aged mice, not surprisingly, the authors observed decreased SIRT1, BMAL1, and PER2 expression in the SCN of aged mice. The authors also observed a partial rescue in aged mice's ability to entrain to a photoperiod shift when SIRT1 was overexpressed in the brain [109].

\section{Might age-induced epigenetic changes in circadian rhythms contribute to memory impairments?}

While there are age-induced changes in some epigenetic mechanisms in the SCN and hippocampus, it is unclear if these changes are contingent on each other. Based on the behavioural data from our lab, which suggests that the degree of circadian rhythm entrainment influences memory in both young and aged rodents, we believe that the SCN becomes dysfunctional with age and this circadian rhythm disruption then affects hippocampal functioning, which elicits cognitive impairments. There are a myriad of ways in which circadian rhythm dysfunction could affect hippocampal functioning $[2,58]$; we discuss one possibility in which epigenetic changes in the SCN elicit circadian dysfunction, which then induces epigenetic changes in the hippocampus (see Figure 1).

As mentioned above, DNA methyltransferase and SIRT1 expression are attenuated by aging in the SCN, and these mechanisms each affect the ability of mice to entrain to a new photoperiod $[91,109]$. Therefore, SCN epigenetic changes in aged animals can elicit circadian rhythm dysfunction, and there is recent evidence that suggests that circadian rhythm dysfunction can affect the hippocampal 
epigenome. For example, in the hippocampus, Perl is required for the rhythmic oscillations of various histone modifications, such as SIRT1, and learning-induced epigenetic changes [32]. These data suggest that clock genes modulate epigenetic changes in the hippocampus. These results should be interpreted with caution, as the Perl mutation was global, so it is unclear if the deficits were due to disrupted oscillations in the hippocampus or were caused by aberrant outputs from the SCN.

Environmental manipulations that elicit circadian rhythm disruption might help determine if hippocampal epigenetic changes induced by circadian disruption are due to the uncoupling of the hippocampus with the SCN (see Figure 1). As previously mentioned, Azzi and colleagues [91] demonstrated that DNA methylation fluctuates in the SCN depending on the photoperiod and regulates entrainment to a new photoperiod. However, SIRT1 expression has not been evaluated in the SCN or hippocampus of rodents in which circadian rhythms have been disrupted by altering the light cycle. Nonetheless, in addition to the transgenic mouse model mentioned above, several studies have used manipulations that likely have induced circadian disruption. A relatively brief period of sleep deprivation alters the phase of locomotor activity rhythms [255] and large reductions in the amplitude of electrical activity in the SCN that lasts for hours after sleep deprivation [256]. With this in mind, five days of total sleep deprivation resulted in attenuated hippocampal SIRT1 expression in rats with concomitant impairments in a rapid acquisition version of the MWT

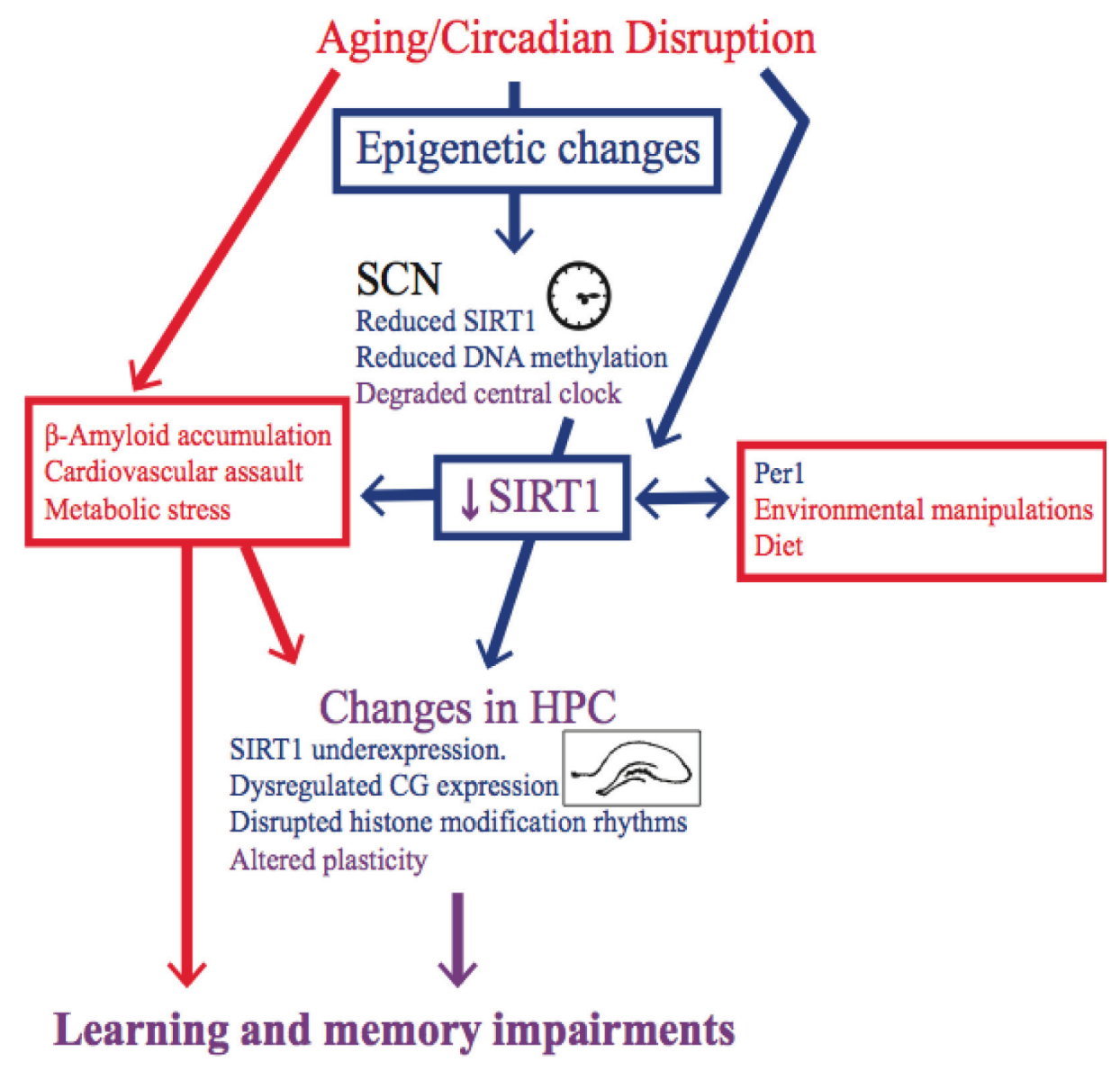

Figure 1: Epigenetic changes are a possible mechanism for the memory impairment induced by circadian rhythm disruption. The blue items are either epigenetic mechanisms or affected by changes in the epigenome, whereas the red items either elicit non-epigenetic mechanisms or are affected by them. The purple items are believed to be effected by both epigenetic and nonepigenetic mechanisms. Factors that induce circadian rhythm disruption, such as aging or shift work, change the epigenome in the SCN, and these changes contribute to SCN dysfunction. SCN dysfunction then affects the epigenome in peripheral oscillators, such as the hippocampus, which contribute to learning and memory impairments. Other factors, such as diet and environmental manipulations could also create learning and memory impairments by changing the epigenome in the hippocampus. It should be noted however that some of these environmental manipulations might also influence circadian rhythms. Alternatively, in addition to circadian rhythm disruption, the memory impairment induced by aging could be a result of other risk factors that impact hippocampal functioning. However, these risk factors are likely exacerbated by circadian rhythm disruption, and this effect could be mediated by changes in the epigenome. 
[257]. Although these authors did not measure circadian rhythm entrainment, it is inconceivable that these rats were not experiencing circadian rhythm dysfunction. Similarly, high-fat diets alter the period of the locomotor activity rhythm and disrupt clock gene oscillations in some peripheral tissues [258]. Mice given a highfat diet for 23 weeks had reduced SIRT1 expression in the hippocampus and concomitant impairments in the object location memory task, which is thought to be a hippocampal-dependent task [259]. Again, the authors did not measure circadian entrainment, but these animals most likely had disrupted circadian rhythms. These data suggest that circadian rhythm disruption can cause epigenetic dysfunction in the hippocampus, which would then affect the signal transduction pathway that is required for memory acquisition, consolidation, and retrieval.

There is another way in which epigenetic-induced SCN dysfunction could contribute to age-related cognitive impairment. We have proposed that age-related dementia or cognitive decline is due to the combined effect of risk factors that affect hippocampal functioning [260-262]. The idea is that cognitive impairments and hippocampal pathology are exacerbated when these risk factors are presented concomitantly instead of in isolation [260-262]. Circadian rhythm disruption could make the hippocampus more vulnerable to damaging factors [260-262]. Although preliminary, we recently demonstrated that minihippocampal strokes elicited more degenerating neurons and smaller hippocampal volumes when they were given to rats that had circadian rhythm disruption compared to rats with entrained rhythms (Gidyk et al., under review). Mechanistically, decreased SIRT1 in the hippocampus elicited by circadian rhythm disruption and/or aging could make the brain more susceptible to damaging factors (see Figure 1). For example, as previously mentioned, SIRT1 is a neuroprotective agent that inhibits beta-amyloid formation [102, 248-250]. Whether circadian rhythm dysfunction induced by epigenetic changes is disrupting memory in aged individuals via epigenetic changes in the hippocampus or by increasing hippocampal vulnerability, this mechanism deserves further investigation.

\section{Circadian rhythms and memory are rescued by manipulations that affect the epigenome}

The notion that drugs and environmental manipulations affect the epigenome is particularly enticing. Caloric restriction in aged animals increases longevity, improves memory/cognition, and reduces markers and the onset of neurodegenerative disease [102, 239]. Agerelated impairments in hippocampal-dependent memory, LTP, and NMDA receptor expression in the hippocampus also do not occur in old rats that have received life-long caloric restriction [263, 264]. Caloric restriction also can increase or decrease SIRT1 expression depending on the brain region $[265,266]$. Relatively brief periods of calorie restriction are sufficient to increase SIRT1 protein levels in the hippocampus [254] of aged rats or in the cortex and hippocampus of adult mice [265]. In addition to boosting SIRT1 expression, calorie restriction also improves insulin function and affects the mechanistic target of rapamycin (MTOR) pathway [267, 268]. The nutrient sensing MTOR pathway affects cell growth/division and while activation of this pathway is initially positive, during aging MTOR activity is deleterious because it elicits cellular aging $[102,268]$. Calorie restriction promotes healthy aging by inhibiting the MTOR pathway and SIRT1 is necessary for this effect $[102,268]$.

Similar to food restriction, calorie restriction can also synchronize peripheral oscillators; however, unlike food restriction, calorie restriction can entrain the SCN [269-272]. Interestingly, calorie restriction also increases SIRT1 expression it the SCN and hippocampi of adult mice [265, 266]. Froy and Miskin [272] discuss how improved circadian rhythmicity likely contributes to increased longevity induced by calorie restriction. The finding that calorie restriction affects circadian rhythms in aged rats, mice, and rhesus monkeys supports this notion [273-275]. Furthermore, in contrast to wild-type mice, the period of circadian rhythms and diurnal pattern of food intake is maintained during aging in aMUA mice, which consume $20 \%$ to $30 \%$ less food than wild-type mice [142, $276]$. With this in mind, it would be interesting to assess circadian rhythms and memory in adult calorie-restricted rats exposed to a photoperiod-shifting paradigm.

Melatonin also has an epigenetic effect that influences both circadian rhythms and memory. Melatonin is attenuated in aged female rats and humans [151, 153] and regulates circadian rhythmicity; recently, it has been suggested that melatonin can influence memory [102, 257]. Exogenous melatonin reduces tumor growth that is elicited by circadian rhythm disruption and also mitigates the accompanying decrease in global DNA methylation [126]. In addition to reducing tumor growth, normal melatonin rhythmicity or exogenous melatonin given to rats with disrupted melatonin rhythms prevents resistance to the breast cancer drug tamoxifen [277]. Melatonin has been linked to the SIRT1 pathway and is thought to epigenetically silence genes [73, 102, 257]. Jenwitheesuk and colleagues [102] suggest that the memory impairment that occurs in aged individuals might be due to diminished circadian expression of melatonin and the resultant effect on hippocampal SIRT1 expression. The finding that melatonin partially rescues SCN clock gene expression and hippocampal SIRT1 expression in sleep-deprived rats supports this hypothesis [171, 257].

\section{CONCLUSIONS}

Circadian rhythms influence memory in young and old subjects. Epigenetic mechanisms are necessary for both circadian rhythms and memory, and these mechanisms are affected by aging. It is possible that 
circadian rhythm disruption, partially induced by ageassociated changes in the epigenome, affects epigenetic mechanisms in the hippocampus, which results in memory impairments. Alternatively, circadian rhythm disruption might precipitate other pathologies that affect hippocampal function. If SCN lesions and environmental light manipulations disrupt hippocampal epigenetic mechanisms, then the hypothesis that hippocampal epigenetic mechanisms are disrupted by circadian rhythm degradation would be strengthened. SCN and hippocampal tissue specific knockouts of clock genes and molecules involved in epigenetic function would also help answer this question. Regardless, with this question, it is difficult to infer causation, as aging affects many processes that might impact hippocampal epigenetic function. It would be interesting to see if the degree of circadian rhythm entrainment in aged animals correlates with hippocampal epigenetic function. Nonetheless, epigenetics as a possible mechanism for how circadian rhythm disruption can affect hippocampal-dependent memory is an intriguing hypothesis that deserves further investigation.

\section{ACKNOWLEDGMENTS}

This research line is supported by grants awarded to Robert J. McDonald from Natural Sciences and Engineering Research Council, Canadian Institutes of Health Research, Alzheimer's Society of Canada, and a Canadian Breast Cancer Foundation grant awarded to Olga Kovalchuk and Robert J. McDonald. Scott H. Deibel currently holds a Natural Sciences and Engineering Research Council PGSD-3 scholarship.

\section{COMPETING INTERESTS} interests.

The authors declare that they have no competing

\section{REFERENCES}

1. Straif K, Baan R, Grosse Y, Secretan B, El Ghissassi F, Bouvard V, Altieri A, Benbrahim-Tallaa L, Cogliano V. Carcinogenicity of shift-work, painting, and fire-fighting. Lancet Oncol. 2007;8:1065-6.

2. Zelinski EL, Deibel SH, McDonald RJ. The trouble with circadian clock dysfunction: Multiple deleterious effects on the brain and body. Neurosci Biobehav Rev [Internet]. Elsevier Ltd; 2014;40:80-101. Available from: http://dx.doi. org/10.1016/j.neubiorev.2014.01.007

3. Pandi-perumal SR, Seils LK, Kayumov L, Ralph MR, Lowe A, Moller H, Swaab DF. Senescence, sleep, and circadian rhythms. Ageing Res Rev. 2002;1:559-604.

4. Penner MR, Roth TL, Barnes CA, Sweatt JD. An epigenetic hypothesis of aging-related cognitive dysfunction. Front Aging Neurosci. 2010;2:1-11.
5. Zelinski EL, Tyndall A V., Hong NS, McDonald RJ. Persistent impairments in hippocampal, dorsal striatal, and prefrontal cortical function following repeated photoperiod shifts in rats. Exp Brain Res. 2013;224:125-39.

6. Zelinski EL, Hong NS, McDonald RJ. Persistent impairments in hippocampal function following a brief series of photoperiod shifts in rats. Anim Cogn. 2014;17:127-41.

7. Antoniadis EA, Ko $\mathrm{CH}$, Ralph MR, McDonald RJ. Circadian rhythms, aging and memory. Behav Brain Res. 2000;111:25-37.

8. Tranah GJ, Blackwell T, Stone KL, Ancoli-Isarel S, Paudel ML, Ensrud KE, Cauley JA, Redline S, Hiller TA, Cummings SR, Yaffe K. Circadian actiivty rhythms and risk of incident dementia and MCI in older women. Ann Neurol. 2011;70:722-32.

9. Eckel-Mahan KL, Storm DR. Circadian rhythms and memory: not so simple as cogs and gears. EMBO Rep. 2009;10:584-91.

10. Eckel-Mahan KL, Phan T, Han S, Wang H, Chan GCK, Scheiner ZS, Storm DR. Circadian oscillation of hippocampal MAPK activity and cAmp: implications for memory persistence. Nat Neurosci. 2008;11:1074-82.

11. Jilg A, Lesny S, Peruzki N, Schwegler H, Selbach O, Dehghani F, Stehle JH. Temporal dynamics of mouse hippocampal clock gene expression support memory processing. Hippocampus. 2010;20:377-88.

12. Phan TH, Chan GC-K, Sindreu CB, Eckel-Mahan KL, Storm DR. The diurnal oscillation of MAP (mitogenactivated protein) kinase and adenylyl cyclase activities in the hippocampus depends on the suprachiasmatic nucleus. J Neurosci. 2011;31:10640-7.

13. Orozco-Solis R, Sassone-Corsi P. Circadian clock: Linking epigenetics to aging. Curr Opin Genet Dev [Internet]. Elsevier Ltd; 2014;26:66-72. Available from: http://dx.doi. org/10.1016/j.gde.2014.06.003

14. Barnard AR, Nolan PM. When clocks go bad: Neurobehavioural consequences of disrupted circadian timing. PLoS Genet. 2008;4:1-8.

15. Moore RY. A clock for the ages. Science (80). 1999;284:2102-4.

16. Merrow M, Spoelstra K, Roenneberg T. The circadian cycle: daily rhythms from behaviour to genes. EMBO Rep. 2005;6:930-5.

17. Inouye ST, Kawamura H. Persistance of circadain rhytmicity in a mammalian hypothalamic "Island" Containing the Suprachiasmatic Nucleus. Proc Natl Acad Sci U S A. 1979;76:5962-6.

18. Lowrey PL, Takahashi JS. Genetics of the mammalian circadian system: Photic entrainment, circadian pacemaker mechanisms, and posttranslational regulation. Annu Rev Genet. 2000;34:533-62.

19. Okamura H. Clock Genes in Cell Clocks : roles, actions, and mysteries. J Biol Chem. 2004;19:388-99. 
20. Reppert SM, Weaver DR. Molecular analysis of mammalian circadian rhythms. Annu Rev Physiol [Internet]. 2001;63:647-76. Available from: http://www.ncbi.nlm.nih. gov/pubmed/11181971

21. Jones JR, Tackenberg MC, Mcmahon DG. Manipulating circadian clock neuron firing rate resets molecular circadian rhythms and behavior. Nat Neurosci [Internet]. 2015;18:15. Available from: http://dx.doi.org/10.1038/nn.3937

22. Guilding C, Piggins HD. Challenging the omnipotence of the suprachiasmatic timekeeper: Are circadian oscillators present throughout the mammalian brain? Eur J Neurosci. 2007;25:3195-216.

23. Yamamoto T, Nakahata Y, Soma H, Akashi M, Mamine T, Takumi T. Transcriptional oscillation of canonical clock genes in mouse peripheral tissues. BMC Mol Biol. 2004;5:18

24. Lamont EW, Robinson B, Stewart J, Amir S. The central and basolateral nuclei of the amygdala exhibit opposite diurnal rhythms of expression of the clock protein Period2. Proc Natl Acad Sci U S A. 2005;102:4180-4.

25. Rath MF, Rohde K, Møller M. Circadian oscillations of molecular clock components in the cerebellar cortex of the rat. Chronobiol Int [Internet]. 2012;29:1289-99. Available from: http:/www.ncbi.nlm.nih.gov/pubmed/23131067

26. Rath MF, Rohde K, Fahrenkrug J, Møller M. Circadian clock components in the rat neocortex: Daily dynamics, localization and regulation. Brain Struct Funct. 2013;218:551-62.

27. Yoo S-H, Yamazaki S, Lowrey PL, Shimomura K, Ko CH, Buhr ED, Siepka SM, Hong H-K, Oh WJ, Yoo OJ, Menaker M, Takahashi JS. PERIOD2::LUCIFERASE real-time reporting of circadian dynamics reveals persistent circadian oscillations in mouse peripheral tissues. Proc Natl Acad Sci U S A. 2004;101:5339-46.

28. Cain SW, Karatsoreos I, Gautam N, Konar Y, Funk D, McDonald RJ, Ralph MR. Blunted cortisol rhythm is associated with learning impairment in aged hamsters. Physiol Behav. 2004;82:339-44.

29. Chaudhury D, Colwell CS. Circadian modulation of learning and memory in fear-conditioned mice. Behav Brain Res. 2002;133:95-108.

30. Ko CH, McDonald RJ, Ralph MR. The Suprachiasmatic Nucleus is not Required for Temporal Gating of Performance on a Reward-based Learning and Memory Task. Biol Rhythm Res [Internet]. 2003;34(2):17792. Available from: http://www.tandfonline.com/doi/ abs/10.1076/brhm.34.2.177.14493

31. McDonald RJ, Hong NS, Ray C, Ralph MR. No Time of Day Modulation or Time Stamp on Multiple Memory Tasks in Rats. Learn Motiv [Internet]. 2002;33:230-52. Available from: http://linkinghub.elsevier.com/retrieve/pii/ S0023969001911117

32. Rawashdeh O, Jilg A, Jedlicka P, Slawska J, Thomas L, Saade A, Schwarzacher SW, Stehle JH. PERIOD1 coordinates hippocampal rhythms and memory processing with daytime. Hippocampus. 2014;24:712-23.

33. Deibel SH, Thorpe CM. The effects of response cost and species-typical behaviors on a daily time-place learning task. Learn Behav. 2012;42-53.

34. Mistlberger RE, De Groot MHM, Bossert JM, Marchant EG. Discrimination of circadian phase in intact and suprachiasmatic nuclei-ablated rats. Brain Res. 1996;739:12-8.

35. Davies J a, Navaratnam V, Redfern PH. The effect of phase-shift on the passive avoidance response in rats and the modifying action of chlordiazepoxide. Br J Pharmacol. 1974;51:447-51.

36. Fekete M, van Ree JM, Niesink RJ, de Wied D. Disrupting circadian rhythms in rats induces retrograde amnesia. Physiol Behav. 1985;34:883-7.

37. Fekete M, Van Ree JM, De Wied D. The ACTH- ( 4-9 ) Analog ORG 2766 and Reverse the Retrograde Amnesia Induced by Disrupting Circadian Rhythms in rats. Peptides. 1986;7:563-8.

38. Tapp WN, Holloway FA. Phase shifting circadian rhythms produces retrograde amnesia. Science (80). 1981;211:10568.

39. Stone WS, Rudd RJ, Ragozzino ME, Gold PE. Glucose attenuation of deficits in memory retrieval in altered light: dark cycles. Psychobiology. 1992;20:47-50.

40. Souchay C, Isingrini M, Espagnet L. Aging, episodic memory feeling-of-knowing, and frontal functioning. Neuropsychology. 2000;14:299-309.

41. Tulving E. What Is Episodic Memory ? Curr Dir Psychol Sci. 1993;2:67-70.

42. Gelbard-Sagiv H, Mukamel R, Harel M, Malach R, Fried I. Internally generated reactivation of single neurons in human hippocampus during free recall. Science. 2008;322:96-101.

43. Lux S, Bindrich VN, Markowitsch HJ, Fink GR. Medial temporal lobe activation during autobiographical context memory retrieval of time and place and its dependency upon recency. Neurocase [Internet]. 2013;37-41. Available from: http://www.ncbi.nlm.nih.gov/pubmed/24329012

44. Tulving E, Tulving E, Markowitsch HJ, Markowitsch HJ. Episodic and Declarative Memory: Role of the Hippocampus. Trends Cogn Sci. 1998;204:198-204.

45. Devan BD, Goad EH, Petri HL, Antoniadis EA, Hong NS, Ko CH, Leblanc L, Lebovic SS, Lo Q, Ralph MR, McDonald RJ. Circadian phase-shifted rats show normal acquisition but impaired long-term retention of place information in the water task. Neurobiol Learn Mem. 2001;75:51-62.

46. Craig LA, McDonald RJ. Chronic disruption of circadian rhythms impairs hippocampal memory in the rat. Brain Res Bull. 2008;76:141-51.

47. Deibel SH, Hong NS, Himmler SM, McDonald RJ. The effects of chronic photoperiod shifting on the physiology of female Long-Evans rats. Brain Res Bull [Internet]. Elsevier 
Inc.; 2014;103:72-81. Available from: http://dx.doi. org/10.1016/j.brainresbull.2014.03.001

48. Loh DH, Navarro J, Hagopian A, Wang LM, Deboer T, Colwell CS. Rapid changes in the light/dark cycle disrupt memory of conditioned fear in mice. PLoS One. 2010;5:112.

49. Van der Zee EA, Havekes R, Barf RP, Hut RA, Nijholt IM, Jacobs EH, Gerkema MP. Circadian time-place learning in mice depends on cry genes. Curr Biol. 2008;18:844-8.

50. Wang LM-C, Dragich JM, Kudo T, Odom IH, Welsh DK, O'Dell TJ, Colwell CS. Expression of the circadian clock gene Period2 in the hippocampus: possible implications for synaptic plasticity and learned behaviour. ASN Neuro. 2009;1:139-52.

51. Kondratova AA, Dubrovsky YV, Antoch MP, Kondratov RV. Circadian clock proteins control adaptation to novel environment and memeory formation. Aging (Albany NY). 2010;2:285-97.

52. Wardlaw SM, Phan TH, Saraf A, Chen X, Storm DR. Genetic disruption of the core circadian clock impairs hippocampus-dependent memory. Learn Mem [Internet]. 2014;21:417-23. Available from: http://www.ncbi.nlm.nih. gov/pubmed/25034823

53. Stephan FK, Kovacevic NS. Multiple retention deficit in passive avoidance in rats is eliminated by suprachiasmatic lesions. Behav Biol. 1978;22:456-62.

54. Mansour HA, Talkowski ME, Wood J, Chowdari K V, McClain L, Prasad K, Montrose D, Fagiolini A, Friedman ES, Allen MH, Bowden CL, Calabrese J, El-mallakh RS, et al. Association study of 21 circadian gnes with bipolar 1 disorder, schizoaffective disorder, and schizophrenia. 2009;11:701-10.

55. Nievergelt CM, Kripke DF, Barrett TB, Burg E, Remick RA, Sadovnivk AD, McElroy SL, Keck Jr PE, Schork NJ, Kelsoe JR. Suggestive evidence for association of the circadian genes PERIOD3 and ARNTL with bipolar disorder. Am J Med Genet Part B Neuropsychiatr Genet. 2006;141B:234-41.

56. Ruby NF, Hwang CE, Wessells C, Fernandez F, Zhang P, Sapolsky R, Heller HC. Hippocampal-dependent learning requires a functional circadian system. Proc Natl Acad Sci U S A. 2008;105:15593-8.

57. McDonald RJ, Zelinski EL, Keeley RJ, Sutherland D, Fehr L, Hong, NS. Multiple effects of circadian dysfunction induced by photoperiod shifts: alterations in context memory and food metabolism in the same subjects. Physiology \& Behavior. 2013;118:14-24.

58. Smarr BL, Jennings KJ, Driscoll JR, Kriegsfeld LJ. A time to remember: The role of circadian clocks in learning and memory. Behav Neurosci [Internet]. 2014;128:283-303. Available from: http://www.scopus.com/inward/record. url?eid=2-s2.0-84901821843\&partnerID=tZOtx3y1

59. Feillet CA, Mendoza J, Albrecht U, Pévet P, Challet E. Forebrain oscillators ticking with different clock hands. Mol
Cell Neurosci. 2008;37:209-21.

60. Wakamatsu H, Yoshinobu Y, Aida R, Moriya T, Akiyama M, Shibata S. Restricted-feeding-induced anticipatory activity rhythm is associated with a phase-shift of the expression of mPer1 and mPer2 mRNA in the cerebral cortex and hippocampus but not in the suprachiasmatic nucleus of mice. Eur J Neurosci. 2001;13:1190-6.

61. Barnes CA, McNaughton BL, Goddard G V, Douglas RM, Adamec R. Circadian rhythm of synaptic excitability in rat and monkey central nervous system. Science (80). 1977;197:91-2.

62. Chaudhury D, Wang LM, Colwell CS. Circadain regulation of hippocampal long-term potentiation. J Biol Rhythms [Internet]. 2005;20:225-36. Available from: http://www. ncbi.nlm.nih.gov/pubmed/18554561

63. Albrecht U. Timing to Perfection: The Biology of Central and Peripheral Circadian Clocks. Neuron. 2012;74:246-60.

64. Hastings MH, Reddy AB, Maywood ES. A clockwork web: circadian timing in brain and periphery, in health and disease. Nat Rev Neurosci. 2003;4:649-61.

65. Bedrosian TA, Galan A, Vaughn CA, Weil ZM, Nelson RJ. Light at Night Alters Daily Patterns of Cortisol and Clock Proteins in Female Siberian Hamsters. J Neuroendocrinol. 2013;25:590-6.

66. Sidor MM, McClung CA. Timing matters: using optogenetics to chronically manipulate neural circuitry and rhythms. Front Behav Neurosci [Internet]. 2014;8:41. Available from: http://www.pubmedcentral.nih.gov/ articlerender.fcgi?artid=3924037\&tool=pmcentrez\&render type $=$ abstract

67. Ralph MR, Sam K, Rawashdeh OA, Cain SW, Ko CH. Memory for time of day (time memory) is encoded by a circadian oscillator and is distinct from other context memories. Chronobiol Int [Internet]. 2013;30:5407. Available from: http://www.ncbi.nlm.nih.gov/ pubmed $/ 23428333$

68. Holliday R. DNA methylation and epigenetic inheritance. Philos Trans R Soc london. 1990;326:329-38.

69. Bernstein E, Allis CD. RNA meets chromatin. Genes Dev. 2005;19:1635-55.

70. Kouzarides T. Chromatin Modifications and Their Function. Cell. 2007;128:693-705.

71. Olins AL, Olins DE. Spheroid chromatin units (v bodies). Science. 1974;183:330-2.

72. Goldberg AD, Allis CD, Bernstein E. Epigenetics: A Landscape Takes Shape. Cell. 2007;128:635-8.

73. Korkmaz A, Sanchez-Barcelo EJ, Tan DX, Reiter RJ. Role of melatonin in the epigenetic regulation of breast cancer. Breast Cancer Res Treat. 2009;115:13-27.

74. Ledón-Rettig CC, Richards CL, Martin LB. Epigenetics for behavioral ecologists. Behav Ecol. 2012;24:311-24.

75. Goll MG, Bestor TH. Eukaryotic cytosine methyltransferases. Annu Rev Biochem. 2005;74:481-514. 
76. Asada K, Abe M, Ushijima T. Clinical application of the $\mathrm{CpG}$ island methylator phenotype to prognostic diagnosis in neuroblastomas. J Hum Genet. 2001;58:428-33.

77. Liu Y, Zhang X, Blumenthal RM, Cheng X. A common mode of recognition for methylated $\mathrm{CpG}$. Trends Biochem Sci. 2013;38:177-83.

78. Suzuki H, Yamamoto E, Maruyama R, Ninuma T, Kai M. Biological significance of the $\mathrm{CpG}$ island methylator phenotype. Biochem Biophys Res Commun. 2014;455:3542.

79. Tryndyak VP, Kovalchuk O, Progribny IP. Loss of DNA methylation and histone $\mathrm{H} 4$ lysine 20 trimethylation in human breast cancer cells is associated with aberrant expression of DNA methyltransferase 1, Suv-20h2 histone methyltransferase and methyl-binding proteins. Cancer Biol Ther. 2006;5:65-70.

80. Tryndyak V, Kovalchuk O, Pogribny IP. Identification of differentially methylated sites within unmethylated DNA domains in normal and cancer cells. Anal Biochem. 2006;356:202-7.

81. Nischal S, Bhattacharyya S, Christopeit M, Yu Y, Zhou L, Bhagat TD, Sohal D, Will B, Mo Y, Suzuki M, Paranani A, McDevitt M, Maciejewski JP, Melnick AM, Greally JM, Steidl U, Moliterno A, Verma A. Methylome profiling reveals distinct alterations in phenotypic and mutational subgroups of myeloproliferative neoplasms. Cancer Res. 2013;73:1076-85.

82. Ehrlich M, Lacey M. DNA hypomethylation and hemimethylation in cancer. Adv Exp Med Biol. 2013;754:31-56.

83. Ducasse M, Brown MA. Epigenetic aberrations and cancer. Mol Cancer. 2006;5:60.

84. Almatrafi A, Feichtinger J, Vernon EG, Escobar NG, Wakeman JA, Larcombe LD, McFarlane R. Identification of a class of human cancer germiline genes with transcriptional silencing refractory to the hypomethylating drug 5-aza-2deoxycytidine. Oncoscience. 2014;1:745-50.

85. Shen N, Yan F, Pang J, Wu L-C, Al-Kali A, Litzow MR, Liu S. A nucleolin-DNMT1 regulatory axis in acute myeloid leukemogenesis. Oncotarget [Internet]. 2014;5:5494-509. Available from: http://www.ncbi.nlm. nih.gov/pubmed/25015109

86. Feil R, Fraga MF. Epigenetics and the environment: emerging patterns and implications. Nat Rev Genet [Internet]. Nature Publishing Group; 2012;13:97-109. Available from: http://dx.doi.org/10.1038/nrg3142

87. Gallou-kabani C, Vigé A, Junien C. Lifelong circadian and epigenetic drifts in metabolic syndrome. Epigenetics. 2007;2:137-146.

88. Belinsky SA, Palmisano WA, Gilliland FD, Crooks LA, Divine KK, Winters SA, Grimes MJ, Harms HJ, Tellez CS, Smith TM, Moots PP, Lechner JF, Stidley CA, Crowell RE. Aberrant promoter methylation in bronchial epithelium and sputum from current and former smokers aberrant promoter methylation in bronchial epithelium and sputum from current and former smokers. Cancer Research. 2002;62:2370-2377.

89. Grönniger E, Weber B, Heil O, Peters N, Stäb F, Wenck H, Korn B, Winnefeld M, Lyko F. Aging and chronic sun exposure cause distinct epigenetic changes in human skin. PLoS Genet. 2010;6:6.

90. Qureshi IA, Mehler MF. Epigenetics of sleep and chronobiology. Curr Neurol Neurosci Rep. 2014;14.

91. Azzi A, Dallmann R, Casserly A, Rehrauer H, Patrignani A, Maier B, Kramer A, Brown SA. Circadian behavior is light-reprogrammed by plastic DNA methylation. Nat Neurosci [Internet]. Nature Publishing Group; 2014;17:37782. Available from: http://www.ncbi.nlm.nih.gov/ pubmed $/ 24531307$

92. Crosio C, Cermakian N, Allis CD, Sassone-Corsi P. Light induces chromatin modification in cells of the mammalian circadian clock. 2000;1241-7.

93. Etchegaray J-P, Lee C, Wade PA, Reppert SM. Rhythmic histone acetylation underlies transcription in the mammalian circadian clock. Nature. 2003;421:177-82.

94. Panda S, Antoch MP, Miller BH, Su AI, Schook AB, Straume M, Schultz PG, Kay S a., Takahashi JS, Hogenesch JB. Coordinated transcription of key pathways in the mouse by the circadian clock. Cell. 2002;109:307-20.

95. Storch K-F, Lipan O, Leykin I, Viswanathan N, Davis FC, Wong WH, Weitz CJ. Extensive and divergent circadian gene expression in liver and heart. Nature. 2002;417:78-83.

96. Yan J, Wang H, Liu Y, Shao C. Analysis of gene regulatory networks in the mammalian circadian rhythm. PLoS Comput Biol. 2008;4.

97. Masri S, Sassone-Corsi P. Plasticity and specificity of the circadian epigenome. Nat Neurosci. 2010;13:1324-9.

98. Doi M, Hirayama J, Sassone-Corsi P. Circadian Regulator CLOCK Is a Histone Acetyltransferase. Cell. 2006;125:497508.

99. Hirayama J, Sahar S, Grimaldi B, Tamaru T, Takamatsu K, Nakahata Y, Sassone-Corsi P. CLOCK-mediated acetylation of BMAL1 controls circadian function. Nature. 2007;450:1086-90.

100. Katada S, Sassone-Corsi P. The histone methyltransferase MLL1 permits the oscillation of circadian gene expression. Nat Struct Mol Biol. 2010;17:1414-21.

101. Masri S, Sassone-Corsi P. The circadian clock: a framework linking metabolism, epigenetics and neuronal function. Nat Rev Neurosci [Internet]. Nature Publishing Group; 2013;14:69-75. Available from: http:/www.ncbi.nlm.nih. gov/pubmed/23187814

102. Jenwitheesuk A, Nopparat C, Mukda S, Wongchitrat $\mathrm{P}$, Govitrapong P. Melatonin regulates aging and neurodegeneration through energy metabolism, epigenetics, autophagy and circadian rhythm pathways. Int J Mol Sci [Internet]. 2014;15:16848-84. Available from: http://www. mdpi.com/1422-0067/15/9/16848/ 
103. Zakhary SM, Ayubcha D, Dileo JN, Jose R, Leheste JR, Horowitz JM, Torres G. Distribution analysis of deacetylase SIRT1 in rodent and human nervous systems. Anat Rec. 2010;293:1024-32.

104. Gao J, Wang W-Y, Mao Y-W, Gräff J, Guan J-S, Pan L, Mak G, Kim D, Su SC, Tsai L-H. A novel pathway regulates memory and plasticity via SIRT1 and miR-134. Nature. 2010;466:1105-9.

105. Michán S, Li Y, Chou MM, Parrella E, Long JM, Allard JS, Lewis K, Miller M, Xu W, Mervis RF, Chen J, Guerin KI, Smith LEH, Mcburney MW, Sinclair D a, Baudry M, Cabo $\mathrm{R}$ De, Longo VD. SIRT1 is essential for normal cognitive function and synaptic plasticity. J Neurosci. 2010;30:9695707.

106. Bellet MM, Sassone-Corsi P. Mammalian circadian clock and metabolism - the epigenetic link. J Cell Sci. 2010;123:3837-48.

107. Asher G, Gatfield D, Stratmann M, Reinke H, Dibner C, Kreppel F, Mostoslavsky R, Alt FW, Schibler U. SIRT1 regulates circadian clock gene expression through PER2 deacetylation. Cell. 2008;134:317-28.

108. Nakahata Y, Kaluzova M, Grimaldi B, Sahar S, Hirayama J, Chen D, Guarente LP, Sassone-Corsi P. The NAD+dependent deacetylase SIRT1 modulates CLOCKmediated chromatin remodeling and circadian control. Cell. 2008;134:329-40.

109. Chang HC, Guarente L. SIRT1 mediates central circadian control in the SCN by a mechanism that decays with aging. Cell [Internet]. Elsevier Inc.; 2013;153:1448-60. Available from:http://dx.doi.org/10.1016/j.cell.2013.05.027

110. Roenneberg T, Kuehnle T, Pramstaller PP, Ricken J, Havel M, Guth A, Merrow M. A marker for the end of adolescence. Curr Biol. 2004;14:1038-9.

111. Barclay NL, Eley TC, Parsons MJ, Willis TA, Gregory AM. Monozygotic twin differences in non-shared environmental factors associated with chronotype. J Biol Rhythms [Internet]. 2013;28:51-61. Available from: http://www.ncbi. nlm.nih.gov/pubmed/23382591

112. Wicht H, Korf H-W, Ackermann H, Ekhart D, Fischer C, Pfeffer M. Chronotypes and rhythm stability in mice. Chronobiol Int [Internet]. 2014;31:27-36. Available from: http://www.ncbi.nlm.nih.gov/pubmed/24079808

113. Bollati V, Baccarelli A, Sartori S, Tarantini L, Motta V, Rota F, Costa G. Epigenetic effects of shiftwork on blood DNA methylation. Chronobiol Int. 2010;27:1093-104.

114. Milagro FI, Gómez-Abellán P, Campión J, Martínez JA, Ordovás JM, Garaulet M. CLOCK, PER2 and BMAL1 DNA Methylation: Association with obesity and metabolic syndrome characteristics and monounsaturated fat intake. Chronobiol Int. 2012;29:1180-94.

115. Stevenson TJ, Prendergast BJ. Reversible DNA methylation regulates seasonal photoperiodic time measurement. Proc Natl Acad Sci U S A [Internet]. 2013;110:166516. Available from: http://www.pubmedcentral.nih.gov/ articlerender.fcgi?artid=3799317\&tool=pmcentrez\&render type $=$ abstract

116. Folkard S. Do permanent night workers show circadian adjustment? A review based on the endogenous melatonin rhythm. Chronobiol Int. 2008;25:215-24.

117. Haus E, Smolensky M. Biological clocks and shift work: Circadian dysregulation and potential long-term effects. Cancer Causes Control. 2006;17:489-500.

118. Simon C, Weibel L, Brandenberger G. Twenty-four-hour rhythms of plasma glucose and insulin secretion rate in regular night workers. AM J Physiol Endocrinol Metab. 2000;278:E413-20.

119. Zhu Y, Stevens RG, Hoffman AE, Tjonneland A, Vogel UB, Zheng T, Hansen J. Epigenetic impact of long-term shiftwork: pilot evidence from circadian genes and wholegenome methylation analysis. Chronobiol Int. 2011;28:85261.

120. Schernhammer ES, Laden F, Speizer FE, Willett WC, Hunter DJ, Kawachi I, Colditz GA. Rotating night shifts and risk of breast cancer in women participating in the nurses' health study. J Natl Cancer Inst. 2001;93:1563-8.

121. Hoffman AE, Yi C-H, Zheng T, Stevens RG, Leaderer D, Zhang Y, Holford TR, Hansen J, Paulson J, Zhu Y. Clock in breast tumorigenesis: evidence from genetic, epigenetic, and transcriptional profiling analyses. Cancer Res. 2010;70:145901468.

122. Hoffman AE, Zheng T, Yi C-H, Stevens RG, Ba Y, Zhang Y, Leaderer D, Holford T, Hansen J, Zhu Y. The core clock gene cryptochrome 2 influences breast cancer risk, possibly by mediating hormone signaling. Cancer Prev Res. 2010;3:539-48.

123. Robertson KD. DNA methylation and human disease. Genetics. 2005;6:597-610.

124. Jacobs DI, Hansen J, Fu A, Stevens RG, Tjonneland A, Vogel UB, Zheng T, Zhu Y. Methylation alternations at imprinted genes detected among long-term shiftworkers. Environ Mol Mutagen. 2013;54:141-6.

125. Shi F, Chen X, Fu A, Hansen J, Stevens R, Tjonneland A, Vogel UB, Zheng T, Zhu Y. Abberrant DNA methylation of miR-219 promotoer in long-term shiftworkers. Environ Mol Mutagen. 2013;54:406-13.

126. Schwimmer H, Metzer A, Pilosof Y, Szyf M, Machnes ZM, Fares F, Harel O, Haim A. Light at night and melatonin have opposite effects on breast cancer tumors in mice assessed by growth rates and global DNA methylation. Chronobiol Int [Internet]. 2014;31:144-50. Available from: http://www.ncbi.nlm.nih.gov/pubmed/24131150

127. Day JJ, Sweatt JD. DNA methylation and memory formation. Nat Neurosci. 2010;13:1319-23.

128. Rudenko a, Tsai L-H. Epigenetic regulation in memory and cognitive disorders. Neuroscience [Internet]. IBRO; 2014;264C:51-63. Available from: http://www.ncbi.nlm. nih.gov/pubmed/23291453

129. Levenson JM, O’Riordan KJ, Brown KD, Trinh M a., 
Molfese DL, Sweatt JD. Regulation of histone acetylation during memory formation in the hippocampus. J Biol Chem. 2004;279:40545-59.

130. Dagnas M, Mons N. Region- and age-specific patterns of histone acetylation related to spatial and cued learning in the water maze. Hippocampus. 2013;23:581-91.

131. Alarcón JM, Malleret G, Touzani K, Vronskaya S, Ishii S, Kandel ER, Barco A. Chromatin acetylation, memory, and LTP are impaired in CBP+/- mice: A model for the cognitive deficit in Rubinstein-Taybi syndrome and its amelioration. Neuron. 2004;42:947-59.

132. Korzus E, Rosenfeld MG, Mayford M. CBP histone acetyltransferase activity is a critical component of memory consolidation. Neuron. 2004;42:961-72.

133. Fischer A, Sananbenesi F, Wang X, Dobbin M, Tsai L-H. Recovery of learning and memory is associated with chromatin remodelling. Nature. 2007;447:178-82.

134. Vecsey CG, Hawk JD, Lattal KM, Stein JM, Fabian SA, Attner MA, Cabrera SM, McDonough CB, Brindle PK, Abel T, Wood MA. Histone deacetylase inhibitors enhance memory and synaptic plasticity via CREB:CBP-dependent transcriptional activation. J Neurosci. 2007;27:6128-40.

135. Chwang WB, O'Riordan KJ, Levenson JM, Sweatt JD. ERK/MAPK regulates hippocampal histone phosphorylation following contextual fear conditioning. Learn Mem. 2006;13:322-8.

136. Miller CA, Sweatt JD. Covalent Modification of DNA Regulates Memory Formation. Neuron. 2007;53:857-69.

137. Miller CA, Gavin CF, White JA, Parrish RR, Honasoge A, Yancey CR, Rivera IM, Rubio MD, Rumbaugh G, Sweatt JD. Cortical DNA methylation maintains remote memory. Nat Neurosci [Internet]. Nature Publishing Group; 2010;13:664-6. Available from: http://dx.doi.org/10.1038/ nn. 2560

138. Bourtchuladze R, Frenguelli B, Blendy J, Cioffi D, Schutz G, Silva AJ. Deficient long-term memory in mice with a targeted mutation of the cAMP-responsive element-binding protein. Cell. 1994;79:59-68.

139. Lu Y, Christian K, Lu B. BDNF: A key regulator for protein synthesis-dependent LTP and long-term memory? Neurobiol Learn Mem. 2008;89:312-23.

140. Hall J, Thomas KL, Everitt BJ. Rapid and selective induction of BDNF expression in the hippocampus during contextual learning. Nat Neurosci. 2000;3:533-5.

141. Kesslak JP, So V, Choi J, Cotman CW, Gomez-Pinilla F. Learning upregulates brain-derived neurotrophic factor messenger ribonucleic acid: a mechanism to facilitate encoding and circuit maintenance? Behav Neurosci. 1998;112:1012-9.

142. Gutman R, Genzer Y, Chapnik N, Miskin R, Froy O. Longlived mice exhibit $24 \mathrm{~h}$ locomotor circadian rhythms at young and old age. Exp Gerontol [Internet]. Elsevier Inc.; 2011;46:606-9. Available from: http://dx.doi.org/10.1016/j. exger.2011.02.015
143. Morin LP. Age-Related Changes in Hamster Circadian Period, Entrainment, and Rhythm Splitting. J Biol Rhythms. 1988;3:237-48.

144. Penev PD, Zee PC, Wallen EP, Turek FW. Aging alters the phase-resetting properties of a serotonin agonist on hamster circadian rhythmicity. Am J Physiol. 1995;268:R293-8.

145. Pittendrigh CS, Daan S. Circadian oscillations in rodents: a systematic increase of their frequency with age. Science. 1974; 186:548-50.

146. Possidente B, McEldowney S, Pabon A. Aging lengthens circadian period for wheel-running activity in C57BL mice. Physiol Behav. 1995;57:575-9.

147. Valentinuzzi VS, Scarbrough K, Takahashi JS, Turek FW. Effects of aging on the circadian rhythm of wheel-running activity in C57BL/6 mice. Am J Physiol Integr Comp Physiol. 1997;273.6:R1957-64.

148. Wax TM. Runwheel activity patterns of mature-young and senescent mice: the effect of constant lighting conditions. J Gerontol. 1975;30:22-7.

149. Welsh DK, Richardson GS, Dement WC. Effect of age on the circadian pattern of sleep and wakefulness in the mouse. J Gerontol. 1986;41:579-86.

150. Scarbrough K, Losee-Olson S, Wallen EP, Turek FW. Aging and photoperiod affect entrainment and quantitative aspects of locomotor behavior in Syrian hamsters. Am J Physiol. 1997;272:R1219-25.

151. Skene DJ, Vivien-Roels B, Sparks DL, Hunsaker JC, Pévet $\mathrm{P}$, Ravid D, Swaab DF. Daily variation in the concentration of melatonin and 5-methoxytryptophol in the human pineal gland: effect of age and Alzheimer's disease. Brain Res. 1990;528:170-4.

152. Zisapel N, Tarrasch R, Laudon M. The relationship between melatonin and cortisol rhythms: Clinical implications of melatonin therapy. Drug Dev Res. 2005;65:119-25.

153. Reiter RJ, Craft CM, R JJ, King TS, Richardson BA, Vaughan GM, Vaughan MK. Age-associated reduction in nocturnal pineal melatonin levels in female rats 1. Endocrinology. 1981;109:1295-7.

154. Poeggeler B. Melatonin, aging, and age-related diseases. Endocrine. 2005;27:201-12.

155. Sapolsky RM, Altmann J. Incidence of hypercortisolism and dexamethasone resistance increases with age among wild baboons. Biol Psychiatry. 1991;30:1008-16.

156. Monk TH, Huysse DJ, Reynolds III CF, Kupfer DJ, Houck PR. Circadian temperature rhythms of older people. Exp Gerontol. 1995;30:455-74.

157. Richardson GS, Carskadon MA, Orav EJ, Dement WC. Circadian variations of sleep tendency in elderly and young adult subjects. Sleep J Sleep Res Sleep Med. 1982;5:S8294.

158. Weitzman ED, Moline ML, Czeisler CA, Zimmerman JC. Chronobiology of aging: Temperature, sleep-wake rhythms and entrainment. Neurobiol Aging. 1982;3:299-309.

159. Diekelmann S, Born J. The memory function of sleep. Nat 
Rev Neurosci. 2010;11:114-26.

160. Crowley K, Trinder J, Kim Y, Carrington M, Colrain IM. The effects of normal aging on sleep spindle and K-complex production. Clin Neurophysiol. 2002;113:1615-22.

161. Farajnia S, Deboer T, Rohling JHT, Meijer JH, Michel S. Aging of the suprachiasmatic clock. Neurosci [Internet]. 2013;20:44-55. Available from: http://nro.sagepub.com/ cgi/doi/10.1177/1073858413498936

162. Palomba M, Nygård M, Florenzano F, Bertini G, Kristensson K, Bentivoglio M. Decline of the presynaptic network, including GABAergic terminals, in the aging suprachiasmatic nucleus of the mouse. J Biol Rhythms. 2008;23:220-31.

163. Kalló I, Kalamatianos T, Piggins HD, Coen CW. Ageing and the diurnal expression of mRNAs for vasoactive intestinal peptide and for the VPAC2 and PAC1 receptors in the suprachiasmatic nucleus of male rats. $\mathrm{J}$ Neuroendocrinol. 2004;16:758-66.

164. Kawakami F, Okamura H, Tamada Y, Maebayashi Y, Fukui $\mathrm{K}$, Ibata Y. Loss of day-night differences in VIP mRNA levels in the suprachiasmatic nucleus of aged rats. Neurosci Lett. 1997;222:99-102.

165. Cai A, Lehman MN, Lloyd JM, Wise PM. Transplantation of fetal suprachiasmatic nuclei into middle-aged rats restores diurnal Fos expression in host. Am J Physiol. 1997;272:R422-8.

166. Lupi D, Semo M, Foster RG. Impact of age and retinal degeneration on the light input to circadian brain structures. Neurobiol Aging [Internet]. Elsevier Inc.; 2012;33:38392. Available from: http://dx.doi.org/10.1016/j. neurobiolaging.2010.03.006

167. Zhang Y, Kornhauser JM, Zee PC, Mayo KE, Takahashi JS, Turek FW. Effects of aging on light-induced phase-shifting of circadian behavioral rhythms, FOS expression and CREB phosphorylation in the hamster suprachiasmatic nucleus. Neuroscience. 1996;70:951-61.

168. Hurd MW, Ralph MR. The significance of circadian organization for longevity in the golden hamster. J Biol Rhythms. 1998;13:430-6.

169. Van Reeth O, Zhang Y, Zee PC, Turek FW. Grafting fetal suprachiasmatic nuclei in the hypothalamus of old hamsters restores responsiveness of the circadian clock to a phase shifting stimulus. Brain Res. 1994;643:338-42.

170. Viswanathan N, Davis FC. Suprachiasmatic nucleus grafts restore circadian function in aged hamsters. Brain Res. 1995;686:10-6.

171. Mattam U, Jagota A. Differential role of melatonin in restoration of age-induced alterations in daily rhythms of expression of various clock genes in suprachiasmatic nucleus of male Wistar rats. Biogerontology. 2014;15:25768.

172. Weinert H, Weinert D, Schurov I, Maywood ES, Hastings MH. Impaired expression of the mPer2 circadian clock gene in the suprachiasmatic nuclei of aging mice. Chronobiol Int.
2001;18:559-65.

173. Kolker DE, Fukuyama H, Huang DS, Takahashi JS, Horton TH, Turek FW. Aging alters circadian and light-induced expression of clock genes in golden hamsters. J Biol Rhythms. 2003;18:159-69.

174. Wyse CA, Coogan AN. Impact of aging on diurnal expression patterns of CLOCK and BMAL1 in the mouse brain. Brain Res. 2010;1337:21-31.

175. Cermakian N, Lamont EW, Boudreau P, Boivin DB. Circadian clock gene expression in brain regions of Alzheimer 's disease patients and control subjects. J Biol Rhythms. 2011;26:160-70.

176. Farajnia S, Michel S, Deboer T, VanderLeest HT, Houben T, Rohling JHT, Ramkisoensing A, Yasenkov R, Meijer JH. Evidence for neuronal desynchrony in the aged suprachiasmatic nucleus clock. J Neurosci. 2012;32:5891-9.

177. Aujard F, Herzog ED, Block GD. Circadian rhythms in firing rate of individual suprachiasmatic nucleus neurons from adult and middle-aged mice. Neuroscience. 2001;106:255-61.

178. Tranah GJ, Blackwell T, Ancoli-Israel S, Paudel ML, Ensrud KE, Cauley JA, Redline S, Hiller, Teresa A, Cummings SR, Stone KL. Circadian activity rhythms and mortaility: the study of osteoporotic fractures. 2010;58:28291.

179. Kondratov R V., Kondratova AA, Gorbacheva VY, Vykhovanets O V., Antoch MP. Early aging and agerelated pathologies in mice deficient in BMAL1, the core component of the circadian clock. Genes Dev. 2006;20:1868-73.

180. Dubrovsky Y V., Samsa WE, Kondratov R V. Deficiency of circadian protein CLOCK reduces lifespan and increases age-related cataract development in mice. Aging (Albany NY). 2010;2:936-44.

181. Bonomini F, Filippini F, Hayek T, Aviram M, Keidar S, Rodella LF, Coleman R, Rezzani R. Apolipoprotein E and its role in aging and survival. Exp Gerontol [Internet]. Elsevier Inc.; 2010;45:149-57. Available from: http:// dx.doi.org/10.1016/j.exger.2009.11.006

182. Muffat J, Walker DW. Apolipoprotein D: An overview of its role in aging and age-related diseases. Cell Cycle. 2010;9:269-73.

183. Petersen RC, Smith GE, Waring SC, Ivnik RJ, Tangalos EG, Kokmen E. Mild cognitive impairment. Arch Neurol. 1999;56:303-9.

184. Leube DT, Weis S, Freymann K, Erb M, Jensen F, Heun R, Grodd W, Kircher TT. Neural correlates of verbal episodic memory in patients with MCI and Alzheimer's disease-a VBM study. Int J Geriatr Psychiatry. 2008;23:1114-8.

185. Storandt M. Cognitive Deficits in the early stages of Alzheimer's disease. Curr Dir psycholgical Sci. 2008;17:198-202.

186. Allen TA, Fortin NJ. The evolution of episodic memory. Proc Natl Acad Sci U S A [Internet]. 2013;110 
Suppl:10379-86. Available from: http://www.pnas.org/ content/110/Supplement_2/10379.full

187. Driscoll I, Hamilton DA, Yeo RA, Brooks WM, Sutherland RJ. Virtual navigation in humans: The impact of age, sex, and hormones on place learning. Horm Behav. 2005;47:326-35.

188. Driscoll I, Sutherland RJ. The aging hippocampus: Navigating between rat and human experiments. Rev Neurosci. 2005;16:87-121.

189. Barnes CA. Memory deficits associated with senescence: a neurophysiological and behavioral study in the rat. J Comp Physiol Psychol. 1979;93:74-104.

190. Barnes CA, Nadel L, Honig WK. Spatial memory deficit in senescent rats. Can J Psychol. 1980;34:29-39.

191. Barnes CA, Suster MS, Shen J, McNaughton BL. Multistability of cognitive maps in the hippocampus of old rats. Nature. 1997;388:272-5.

192. Gage FH, Dunnett SB, Björklund A. Spatial learning and motor deficits in aged rats. Neurobiol Aging. 1984;5:43-8.

193. Gerrard JL, Kudrimoti H, McNaughton BL, Barnes CA. Reactivation of hippocampal activity patterns in the aging rat. Behav Neurosci. 2001;115:1180-92.

194. Gerrard JL, Burke SN, McNaughton BL, Barnes CA. Sequence reactivation in the hippocampus is impired in aged rats. J Neurosci. 2008;28:7883-90.

195. Peleg S, Sananbenesi F, Zovoilis A, Burkhardt S, BahariJavan S, Agis-Balboa RC, Cota P, Wittnam JL, GogolDoering A, Opitz L, Salinas-Riester G, Dettenhofer M, Kang H, Farinelli L, Chen W, Fischer A. Altered histone acetylation is associated with age-dependent memory impairment in mice. Science. 2010;328:753-6.

196. Penner MR, Roth TL, Chawla MK, Hoang LT, Roth ED, Lubin FD, Sweatt JD, Worley PF, Barnes C a. Age-related changes in Arc transcription and DNA methylation within the hippocampus. Neurobiol Aging [Internet]. Elsevier Inc.; 2011;32:2198-210. Available from: http://dx.doi. org/10.1016/j.neurobiolaging.2010.01.009

197. Shen J, Barnes CA, McNaughton BL, Skaggs WE, Weaver KL. The effect of aging on experience-dependent plasticity of hippocampal place cells. J Neurosci. 1997;17:6769-82.

198. Keuker JIH, Luiten PGM, Fuchs E. Preservation of hippocampal neuron numbers in aged rhesus monkeys. Neurobiol Aging. 2003;24:157-65.

199. Rapp PR, Gallagher M. Preserved neuron number in the hippocampus of aged rats with spatial learning deficits. Proc Natl Acad Sci U S A. 1996;93:9926-30.

200. West MJ, Coleman PD, Flood DG, Troncoso JC. Differences in the Pattern of Hippocampal Neuronal Loss in Normal Aging and Alzheimers-Disease. Lance. 1994;344:769-72.

201. Burke SN, Barnes CA. Neural plasticity in the ageing brain. Nat Rev Neurosci. 2006; 7:30-40.

202. Driscoll I, Hong NS, Craig LA, Sutherland RJ, McDonald RJ. Enhanced cell death and learning deficits after a mini-stroke in aged hippocampus. Neurobiol Aging. 2008;29:1847-58.

203. Barnes BYCA, Mcnaughton BL. Physiological compensation for loss of afferent synapses in rat hippocampal granule cells during senescence. J Physiol. 1980;309:473-85.

204. Barnes CA, McNaughton BL. An age comparison of the rates of acquisition and forgetting of spatial information in relation to long-term enhancement of hippocampal synapses. Behav Neurosci. 1985;99:1040-8.

205. Barnes CA, Rao G, Houston FP. LTP induction threshold change in old rats at the perforant path-granule cell synapse. Neurobiol Aging. 2000;21:613-20.

206. Shankar S, Teyler TJ, Robbins N. Aging differentially alters forms of long-term potentiation in rat hippocampal area CA1. J Neurophysiol. 1998;79:334-41.

207. Dieguez Jr D, Barea-Rodriguez EJ. Aging impairs the late phase of long-term potentiation at the medial perforant path-CA3 synapse in awake rats. Synapse. 2004;52:53-61.

208. Abel T, Lattal KM. Molecular mechanisms of memory acquistion, consolidation and retrieval. Curr Opin Neurobiol. 2001;11:180-7.

209. Guzowski JF. Insights into immediate-early gene function in hippocampal memory consolidation using antisense oligonucleotide and fluorescent imaging approaches. Hippocampus. 2002;12:86-104.

210. Korte M, Carrolltt P, Wolf E, Brem G, Thoenent H, Bonhoeffer T. Hippocampal long-term potentiation is impaired in mice lacking brain-derived neurotrophic factor. Neurobiology. 1995;92:8856-60.

211. Linnarsson S, Björklund A, Ernfors P. Learning deficit in BDNF mutant mice. Eur J Neurosci. 1997;9:2581-7.

212. Hattiangady B, Rao MS, Shetty GA, Shetty AK. Brainderived neurotrophic factor, phosphorylated cyclic AMP response element binding protein and neuropeptide $\mathrm{Y}$ decline as early as middle age in the dentate gyrus and CA1 and CA3 subfields of the hippocampus. Exp Neurol. 2005;195:353-71.

213. Silhol M, Bonnichon V, Rage F, Tapia-Arancibia L. Agerelated changes in brain-derived neurotrophic factor and tyrosine kinase receptor isoforms in the hippocampus and hypothalamus in male rats. Neuroscience. 2005;132:613-24.

214. Silhol M, Arancibia S, Maurice T, Tapia-Arancibia L. Spatial memory training modifies the expression of brainderived neurotrophic factor tyrosine kinase receptors in young and aged rats. Neuroscience. 2007;146:962-73.

215. Tapia-Arancibia L, Aliaga E, Silhol M, Arancibia S. New insights into brain BDNF function in normal aging and Alzheimer disease. Brain Res Rev [Internet]. Elsevier B.V.; 2008;59:201-20. Available from: http://dx.doi. org/10.1016/j.brainresrev.2008.07.007

216. Blalock EM, Chen K-C, Sharrow K, Herman JP, Porter NM, Foster TC, Landfield PW. Gene microarrays in hippocampal aging: statistical profiling identifies novel 
processes correlated with cognitive impairment. J Neurosci. 2003;23:3807-19.

217. Rowe WB, Blalock EM, Chen K-C, Kadish I, Wang D, Barrett JE, Thibault O, Porter NM, Rose GM, Landfield PW. Hippocampal expression analyses reveal selective association of immediate-early, neuroenergetic, and myelinogenic pathways with cognitive impairment in aged rats. J Neurosci. 2007;27:3098-110.

218. O'Keefe J, Dostrovsky J. The hippocampus as a spatial map. Preliminary evidence from unit activity in the freelymoving rat. Brain Res. 1971;34:171-5.

219. Moser EI, Kropff E, Moser M-B. Place cells, grid cells, and the brain's spatial representation system. Annu Rev Neurosci. 2008;31:69-89.

220. Eichenbaum H, MacDonald CJ, Kraus BJ. Time and the hippocampus. Space, Time and Memory in the Hippocampal Formation. 2014. p. 273-301.

221. Eichenbaum H, Dudchenko P, Wood E, Shapiro M, Tanila $\mathrm{H}$. The hippocampus, memory, and place cells: Is it spatial memory or a memory space? Neuron. 1999;23:209-26.

222. Frank LM, Brown EN, Wilson M. Trajectory encoding in the hippocampus and entorhinal cortex. Neuron. 2000;27:169-78.

223. Frank LM, Brown EN, Stanley GB. Hippocampal and cortical place cell plasticity: implications for episodic memory. Hippocampus. 2006;16:775-84.

224. Wood ER, Dudchenko PA, Robitsek RJ, Eichenbaum H. Hippocampal neurons encode information about different types of memory episodes occurring in the same location. Neuron. 2000;27:623-33.

225. Ferbinteanu J, Shapiro ML. Prospective and retrospective memory coding in the hippocampus. Neuron. 2003;40:122739.

226. Mizumori SJY, Kalyani A. Age and experience-dependent representational reorganization during spatial learning. Neurobiol Aging. 1997;18:651-9.

227. Tanila H, Sipilä P, Shapiro M, Eichenbaum H. Brain aging: impaired coding of novel environmental cues. J Neurosci. 1997; 17:5167-74.

228. Mehta MR, Barnes CA, McNaughton BL. Experiencedependent, asymmetric expansion of hippocampal place fields. Proc Natl Acad Sci U S A. 1997;94:8918-21.

229. Yan J, Zhang Y, Roder J, McDonald RJ. Aging effects on spatial tuning of hippocampal place cells in mice. Exp Brain Res [Internet]. 2003;150:184-93. Available from: http:// www.ncbi.nlm.nih.gov/pubmed/12677315

230. Foster DJ, Wilson MA. Reverse replay of behavioural sequences in hippocampal place cells during the awake state. Nature. 2006;440:680-3.

231. Pavlides C, Winson J. Influences of hippocampal place cell firing in the awake state on the activity of these cells during subsequent sleep episodes. J Neurosci. 1989;9:2907-18.

232. Wilson MA, McNaughton BL. Reactivation of Hippocampal Ensemble memories during sleep. Science
(80- ). 1994;265:678-9.

233. Jadhav SP, Frank LM. Memory replay in the hippocampus. Space, Time and Memory in the Hippocampal Formation. 2014. p. 351-71.

234. Tononi G, Cirelli C. Sleep and the Price of Plasticity: From Synaptic and Cellular Homeostasis to Memory Consolidation and Integration. Neuron [Internet]. Elsevier Inc.; 2014;81:12-34. Available from: http://dx.doi. org/10.1016/j.neuron.2013.12.025

235. Munn RGK, Bilkey DK. The firing rate of hippocampal CA1 place cells is modulated with a circadian period. Hippocampus. 2012;22:1325-37.

236. Calvanese V, Lara E, Kahn A, Fraga MF. The role of epigenetics in aging and age-related diseases. Ageing Res Rev. 2009;8:268-76.

237. Fuke C, Shimabukuro M, Petronis A, Sugimoto J, Oda T, Miura K, Miyazaki T, Ogura C, Okazaki Y, Jinno Y. Age related changes in 5-methylcytosine content in human peripheral leukocytes and placentas: An HPLC-based study. Ann Hum Genet. 2004;68:196-204.

238. Wilson VL, Smith RA, Ma S, Cutler RG. Genomic 5-methyldeoxycytidine decreases with age. J Biol Chem. 1987;262:9948-51.

239. Moskalev AA, Aliper AM, Smit-McBride Z, Buzdin A, Zhavoronkov A. Genetics and epigenetics of aging and longevity. Cell Cycle. 2014;13:1063-77.

240. Ryan JM, Cristofalo VJ. Histone acetylation during aging of human cells in culture. Biochem Biophys Res Commun. 1972;48:735-42.

241. Lee CT, Duerre JA. Changes in histone methylase activity of rat brain and liver with ageing. Nature. 1974;251:240-2.

242. Sasaki T, Maier B, Bartke A, Scrable H. Progressive loss of SIRT1 with cell cycle withdrawal. Aging Cell. 2006;5:41322.

243. Coppieters N, Dieriks B V., Lill C, Faull RLM, Curtis MA, Dragunow M. Global changes in DNA methylation and hydroxymethylation in Alzheimer's disease human brain. Neurobiol Aging [Internet]. Elsevier Ltd; 2014;35:133444. Available from: http://dx.doi.org/10.1016/j. neurobiolaging.2013.11.031

244. Sidler C, Woycicki R, Kovalchuk I, Kovalchuk O. WI 38 senescence is associated with global and site specific hypomethylation. Aging (Albany NY). 2014;6:564-74.

245. Sidler C, Woycicki R, Li D, Wang B, Kovalchuk I, Kovalchuk O. A role for SUV39H1-mediated H3K9 trimethylation in the control of genome stability and senescence in WI38 human diploid lung fibroblasts. Aging (Albany NY). 2014;6:545-63.

246. Sidler C, Wóycicki R, Ilnytskyy Y, Metz G, Kovalchuk I, Kovalchuk O. Immunosenescence is associated with altered gene expression and epigenetic regulation in primary and secondary immune organs. Front Genet [Internet]. 2013;4:211. Available from: http://www.pubmedcentral. nih.gov/articlerender.fcgi?artid $=3798808 \&$ tool $=$ pmcentrez 
\&rendertype $=$ abstract

247. Kim D, Nguyen MD, Dobbin MM, Fischer A, Sananbenesi F, Rodgers JT, Delalle I, Baur J a, Sui G, Armour SM, Puigserver P, Sinclair D a, Tsai L-H. SIRT1 deacetylase protects against neurodegeneration in models for Alzheimer's disease and amyotrophic lateral sclerosis. EMBO J. 2007;26:3169-79.

248. Brunet A, Berger SL. Epigenetics of aging and agingrelated disease. Journals Gerontol - Ser A Biol Sci Med Sci. 2014;69:17-20.

249. Kim D, Nguyen MD, Dobbin MM, Fischer A, Sananbenesi F, Rodgers JT, Delalle I, Baur JA, Sui G, Armour SM, Puigserver P, Sinclair DA, Tsai L-H. SIRT1 deacetylase protects against neurodegeneration in models for Alzheimer's disease and amyotrophic lateral sclerosis. EMBO J. 2007;26(May):3169-79.

250. Qin W, Zhao W, Ho L, Wang J, Walsh K, Gandy S, Paslnetti GM. Regulation of forkhead transcription factor Fox03a contributes to calorie restriction-induced prevention of Alzheimer's disease-type amyloid neuropathology and spatial memory detrioration. ANN N Y Acad Sci. 2008;1147:335-47.

251. Sommer M, Poliak N, Upadhyay S, Ratovitski E, Nelkin BD, Donehower L a., Sidransky D. $\Delta$ Np63 $\alpha$ overexpression induces downregulation of Sirt1 and an accelerated aging phenotype in the mouse. Cell Cycle. 2006;5(February 2015):2005-11.

252. Satoh A, Brace CS, Rensing N, Cliften P, Wozniak DF, Herzog ED, Yamada KA, Imai SI. Sirtl extends life span and delays aging in mice through the regulation of $\mathrm{Nk} 2$ Homeobox 1 in the DMH and LH. Cell Metab [Internet]. Elsevier Inc.; 2013;18:416-30. Available from: http:// dx.doi.org/10.1016/j.cmet.2013.07.013

253. Dagnas M, Guillou J-L, Prevot T, Mons N. HDAC inhibition facilitates the switch between memory systems in young but not aged mice. J Neurosci [Internet]. 2013;33:1954-63. Available from: http://www.jneurosci. org/cgi/doi/10.1523/JNEUROSCI.3453-12.2013

254. Quintas A, de Solis AJ, Díez FJ, Carrascosa JM, Bogónez E. Age-associated decrease of SIRT1 expression in rat hippocampus. Prevention by late onset caloric restriction. Exp Gerontol [Internet]. Elsevier Inc.; 2012;47:198201. Available from: http://dx.doi.org/10.1016/j. exger.2011.11.010

255. Antle MC, Mistlberger RE. Circadian clock resetting by sleep deprivation without exercise in the Syrian hamster. J Neurosci. 2000;20:9326-32.

256. Deboer T, Détári L, Meijer JH. Long term effects of sleep deprivation on the mammalian circadian pacemaker. Sleep. 2007;30:257-62.

257. Chang HM, Wu UI, Lan CT. Melatonin preserves longevity protein (sirtuin 1) expression in the hippocampus of total sleep-deprived rats. J Pineal Res. 2009;47:211-20.

258. Kohsaka A, Laposky AD, Ramsey KM, Estrada C, Joshu
C, Kobayashi Y, Turek FW, Bass J. High-fat diet disrupts behavioral and molecular circadian rhythms in mice. Cell Metab. 2007;6:414-21.

259. Heyward FD, Walton RG, Carle MS, Coleman MA, Garvey WT, Sweatt JD. Adult mice maintained on a highfat diet exhibit object location memory deficits and reduced hippocampal SIRT1 gene expression. Neurobiol Learn Mem [Internet]. Elsevier Inc.; 2012;98:25-32. Available from: http://dx.doi.org/10.1016/j.nlm.2012.04.005

260. Craig LA, Hong NS, McDonald RJ. Revisiting the cholinergic hypothesis in the development of Alzheimer's disease. Neurosci Biobehav Rev [Internet]. Elsevier Ltd; 2011;35:1397-409. Available from: http://dx.doi. org/10.1016/j.neubiorev.2011.03.001

261. McDonald RJ. Multiple combinations of co-factors produce variants of age-related cognitive decline: a theory. Can J Exp Psychol. 2002;56:221-39.

262. McDonald RJ, Craig LA, Hong NS. The etiology of agerelated dementia is more complicated than we think. Behav Brain Res. 2010;214:3-11.

263. Pitsikas N, Algeri S. Deterioration of spatial and nonspatial reference and working memory in aged rats: Protective effect of life-long calorie restriction. Neurobiol Aging. 1992;13:369-73.

264. Eckles-Smith K, Clayton D, Bickford P, Browning MD. Caloric restriction prevents age-related deficits in LTP and in NMDA receptor expression. Mol Brain Res. 2000;78:154-62.

265. Chen D, Steele AD, Hutter G, Bruno J, Govindarajan A, Easlon E, Lin SJ, Aguzzi A, Lindquist S, Guarente L. The role of calorie restriction and SIRT1 in prion-mediated neurodegeneration. Exp Gerontol [Internet]. Elsevier Inc.; 2008;43:1086-93. Available from: http://dx.doi. org/10.1016/j.exger.2008.08.050

266. Satoh A, Brace CS, Ben-Josef G, West T, Wozniak DF, Holtzman DM, Herzog ED, Imai S. SIRT1 promotes the central adaptive response to diet restriction through activation of the dorsomedial and lateral nuclei of the hypothalamus. J Neurosci. 2010;30:10220-32.

267. Bartke A. Insulin and aging. Cell Cycle. 2008;7:3338-43.

268. Blagosklonny M V. MTOR-driven quasi-programmed aging as a disposable soma theory Blind watchmaker vs. intelligent designer. Cell Cycle. 2013;12:1842-7.

269. Damiola F, Le Minli N, Preitner N, Kornmann B, FleuryOlela F, Schibler U. Restricted feeding uncouples circadian oscillators in peripheral tissues from the central pacemaker in the suprachiasmatic nucleus. Genes Dev. 2000;14:295061.

270. Hara R, Wan K, Wakamatsu H, Aida R, Moriya T, Akiyama M, Shibata S. Restricted feeding entrains liver clock without participation of the suprachiasmatic nucleus. Genes to Cells. 2001;6:269-78.

271. Mendoza J, Graff C, Dardente H, Pevet P, Challet E. Feeding cues alter clock gene oscillations and photic 
responses in the suprachiasmatic nuclei of mice exposed to a light/dark cycle. J Neurosci. 2005;25:1514-22.

272. Froy O, Miskin R. Effect of feeding regimens on circadian rhythms: Implications for aging and longevity. Aging (Albany NY). 2010;2:7-27.

273. Duffy PH, Feuers RJ, Leakey JA, Nakamura KD, Turturro A, Hart RW. Effect of chronic caloric restriction on physiological variables related to energy metabolism in the male fischer 344 rat. Mech Ageing Dev. 1989;48:117-33.

274. Duffy PH, Feuers RJ, Hart RW. Effect of chronic caloric restriction on the circadian regulation of lysiological and behavioral variables in old male B6C3F1 mice. Chronobiol Int. 1990;7:291-303.

275. Weed JL, Lane M a., Roth GS, Speer DL, Ingram DK. Activity measures in rhesus monkeys on long-term calorie restriction. Physiol Behav. 1997;62:97-103.

276. Froy O, Miskin R. The interrelations among feeding, circadian rhythms and ageing. Prog Neurobiol. 2007;82:142-50.

277. Dauchy RT, Xiang S, Mao L, Brimer S, Wren M a., Yuan L, Anbalagan M, Hauch A, Frasch T, Rowan BG, Blask DE, Hill SM. Circadian and melatonin disruption by exposure to light at night drives intrinsic resistance to tamoxifen therapy in breast cancer. Cancer Res. 2014;74:4099-110. 